\title{
The Impact of Different Phases of the El Niño- Southern Oscillation Phenomenon on Goiás State Rainfalls and Temperature Characteristics Across Three Decades
}

\section{David Henriques da Matta}

Institute of Mathematics and Statistics (IME)

Caio Augusto dos Santos Coelho

Instituto Nacional de Pesquisas Espaciais (INPE)

Leydson Lara dos Santos

Institute of Mathematics and Statistics (IME)

Luis Fernando Stone

Embrapa Arroz e Feijão

Alexandre Bryan Heinemann ( $\nabla$ alexandre.heinemann@embrapa.br)

Embrapa Arroz e Feijão https://orcid.org/0000-0002-7037-488X

\section{Research Article}

Keywords: El Niño-Southern Oscillation (ENSO), Goiás State, mega-regions, rainfed season

Posted Date: August 26th, 2021

DOI: https://doi.org/10.21203/rs.3.rs-762347/v1

License: (c) (1) This work is licensed under a Creative Commons Attribution 4.0 International License.

Read Full License 
The impact of different phases of the El Niño-Southern Oscillation phenomenon on Goiás State rainfalls and temperature characteristics across three decades

David Henriques da Matta ${ }^{1}$; Caio Augusto dos Santos Coelho² ${ }^{2}$ Leydson Lara dos Santos $^{1}$; Luis Fernando Stone ${ }^{3}$; Alexandre Bryan Heinemann ${ }^{3 *}$

${ }^{1}$ Federal University of Goiás (UFG), Institute of Mathematics and Statistics (IME), Campus II -Av. Esperança, s/n Instituto de Matemática e Estatística, Samambaia, Goiânia GO, 74001-970, e-mail: dhmatta@ufg.br; consult.leydson@gmail.com

${ }^{2}$ Centro de Previsão de Tempo e Estudos Climáticos (CPTEC), Instituto Nacional de Pesquisas Espaciais (INPE), Rodovia Presidente Dutra, Km 40, SP-RJ, Cachoeira Paulista, SP, 12630-000, Brazil, email: caio.coelho@inpe.br

${ }^{3}$ Embrapa Arroz e Feijão, Rodovia GO-462 km 12 Zona Rural, 75375-000 Santo Antônio de Goiás, GO, Brazil, e-mail: Luis.stone@embrapa.br; alexandre.heinemann@embrapa.br (ORCID: https://orcid.org/0000-0002-7037-488X)

*Corresponding author: Alexandre Bryan Heinemann

(alexandre.heinemann@embrapa.br); Tel: +55 6235332153

Target Journal: Theoretical and Applied Climatology
Abstract
Rainfall and temperature are the two key parameters of crop development. Studying the characteristics of these parameters under El Niño-Southern Oscillation (ENSO) conditions is important to better understand the impacts of the different phases of this phenomenon (El Niño, Neutral, and La Niña conditions) on agriculture. This study analyzes 32 years (1980-2011) of climatic data from 128 weather stations across 
Goiás State in Brazil to determine the behavior of temperature and rainfall time series over three periods (1980-1989; 1990-1999 and 2000-2011) under El Niño, Neutral, and La Niña conditions. The analysis revealed no major impacts of ENSO conditions on accumulated rainfall characteristics, a feature particularly marked in the most recent period (2000-2011). ENSO impacting temperature was identified but presented considerable variability across the periods investigated. These impacts were marked in the first two periods as for maximum temperature and increased from the first to the last period as for minimum temperature. These features were noticed in both analyses in the entire Goiás State and most of the investigated mega-regions, except for the East and Northeast mega-regions as for minimum temperature. There were increases in maximum temperature values throughout the rainfed season (October to March) for all ENSO conditions and investigated periods. Minimum temperature also increased across the three investigated periods, and this was marked in the beginning of the rainfed season (October) under El Niño and Neutral conditions.

\section{Introduction}

Brazil expects to produce 272.3 millions of tons of grains in the $2020 / 2021$ season (CONAB 2021). The primary region of grain production (mainly soybean and maize) in Brazil is the Midwest region. Agricultural expansion in this region over the last three decades has been driven largely by the international commodity market (Verburg et al. 2014a, b). In this scenario, the Goiás State, the second largest grain producing State in Midwest region with a cultivated area of 27.3 thousand hectares, plays an important role in Brazil's agricultural gross domestic product. Regional farming and production are highly dependent on the rainy season. In addition, the electricity sector also exerts enormous pressure on water resources, since $8.6 \%$ $(11,170 \mathrm{MW})$ of the national electricity generation originates in the State of Goiás 
(Pereira Júnior and Nicácio 2015). Therefore, rainfall variability significantly affects the socio-economic well-being of the region's population, as its livelihoods and food security depend on these rainfed crop systems (PBMC 2014; Abrahão and Costa 2018). Besides, climate and weather affect crop area, intensity, and yield in different ways (Iizumi and Ramankutty 2015).

The El Niño-Southern Oscillation (ENSO) is the main phenomenon that modulates interannual rainfall variability in South America (Souza et al. 2021). Specifically in Brazil, excess of rainfalls usually occurs in southern Brazil during the austral spring of hot (El Niño) years (Santos et al. 2021; Souza et al. 2021), as well as during the subsequent summer. Rainfall deficits usually occur in the Brazilian north and northeastern due to the austral winter of the El Niño onset year to the fall of the following year. A reversed rainfall pattern to the one described above usually occurs during the cold ENSO (La Niña) phase (Andreoli and Kayano 2006; Grimm and Tedeschi 2009; Kayano et al. 2013). Central Brazil is classified as a transitional region (Grimm 2003; Penalba and Rivera 2016; Moura et al. 2019; Nóia Júnior and Sentelhas 2019). ENSO impacts are not as characteristic as in the Brazilian southern and northeastern. However, the negative ENSO phase (La Niña) may substantially reduce the number of dry days during the rainy season across the entire Central Brazil region, and La Niña also delays the start of the growing season (Heinemann et al. 2021). In this study, we hypothesize that the differentiation of ENSO impacts on rainfall and temperature in Central Brazil are not as evident as in the Brazilian south and northeastern regions due to similarity to ENSO (La Niña, El Niño, and Neutral) patterns across some decades.

The general objective of this study is to determine the characteristics and quantify the dissimilarities in rainfall and temperature time series in three periods (1980-1989, 
1990-1999 and 2000-2011) under the different phases of the El Niño Southern Oscillation (ENSO) phenomenon in Central Brazil.

\section{Materials and Methods}

\subsection{Regional setting}

The study area covers part of the Cerrado biome (Brazilian savanna) and is concentrated in the Goiás State. The region has a surface area of ca. 340,086 million $\mathrm{km}^{2}$ (IBGE, 2020), which accounts for 3.99\% of the Brazilian territory. Altitude, latitude, and longitude ranges from $0-1,200 \mathrm{~m}$ above mean sea level, $19^{\circ}(\mathrm{S})$ to $15^{\circ}(\mathrm{S})$, and $46^{\circ}(\mathrm{S})$ to $51^{\circ}(\mathrm{S})$ (Figure $\left.1 \mathrm{~A}, \mathrm{~B}\right)$. The predominant climate in the region is tropical savanna (Aw), which accounts for $94 \%$ of the total area (Alvares et al. 2013) (Figure 1C). Due to its annual cycle, the wet season is from October to March, and the dry season is from April to September, highlighting monsoonal rainfall characteristics in this region (monomodal pattern) (Prado et al. 2021). More than $80 \%$ of the total annual rainfall are in the wet season (between October and March), with the largest rainfall volumes recorded from January to March (Heinemann et al. 2021). The annual rainfall in the study region ranges from 1,130 to $2,040 \mathrm{~mm}$, with a mean of $1,515 \mathrm{~mm}$. The highest maximum temperature values $\left(33^{\circ} \mathrm{C}\right.$ to $\left.35^{\circ} \mathrm{C}\right)$ occur in August, September, and October. The lowest minimum temperature values range on average 12 to $16^{\circ} \mathrm{C}$ and are observed during this same period (Silva et al. 2018). The study region is divided politically into five mega-regions, namely Center, East, Northeast, North, and South (Figure 1A).

\subsection{Meteorological data}

We used daily rainfall, maximum, and minimum temperature time series obtained from the Brazilian Institute of Meteorology (INMET), the Water National Agency 
(ANA), the Goiás Meteorological and Hydrological Information Center (CIMEHGO), and the Brazilian Agricultural Research Corporation (EMBRAPA). We selected 121 meteorological weather stations to cover the entire study region (Figure 1). We obtained continuous meteorological records between 1980 and 2011 (32 years) from each station. These data sets were quality-controlled, checked for homogeneity, and gap-filled to fill missing data and possible outliers due to human-induced errors or faulty measuring equipment (Ramirez-Villegas and Challinor 2012; Van Wart et al. 2015). To fill the gaps in the dataset we gathered data from the gridded meteorological dataset developed by Xavier et al. (2016). We ran visual checks of the final time series data set (1980-2011) to ensure data was free of implausible characteristics. The "gap-filling" method is described in detail in Ramirez-Villegas et al. (2018) and Heinemann et al. (2019). Missing rainfall data in most stations occurred in approximately $20 \%$ of the total number of days.

\subsubsection{Data set organization}

Rainfed agricultural system predominates in the study region. For this reason, we considered only the wet season (from October to March) to analyze rainfall and temperature characteristics. Each rainfed season starts on October 1 of one year and ends on March 31 of the next year. We did not consider February 29 in leap years. To minimize noise introduced by days with no rainfall (zero $\mathrm{mm}$ ), which could make the statistical process much more complex, we computed the weekly accumulated rainfall values from October to March (rainfed season). For maximum and minimum temperatures, and also to minimize noise, we computed only the weekly maximum and minimum temperature values from October to March (rainfed season). Therefore, for climate variables, accumulated rainfall and temperatures values, we obtained 26 (weeks) equidistant points that we plotted into a curve per rainfed season. Each curve 
has unique observation times in that interval, hereafter referred to as number of season curve. At this point, we ran a second visual check on the curves and ensured again that data were free of implausible characteristics.

Table 1 shows the numbers of season curves for each ENSO phenomenon (La Niña, El Niño, and Neutral) and period (\# of season curves), also shown in Figure S1 of the supplementary information material (only for the variable accumulated rainfall for the 1980-1989 period).

\subsection{ENSO data}

ENSO conditions are typically defined by sea surface temperature (SST) variations and their persistence along the equatorial Pacific Ocean (NOAA 2019). The National Oceanic and Atmospheric Administration (NOAA) defines El Niño and La Niña events based on a threshold temperature anomaly of $\pm 0.5^{\circ} \mathrm{C}$ for the Oceanic Niño Index (ONI), which in turn is computed as the three-month running mean of SST anomalies across the Eastern Equatorial Pacific (Bhuvaneswari et al. 2013). As the rainfall season occurs between October and March in the study region, we averaged ONI values of October, November, and December (OND) to January, February, and March (JFM). For the purpose of our analysis, averaged ONI values lower than -0.5 ${ }^{\circ} \mathrm{C}$ are considered La Niña years, values higher than $0.5^{\circ} \mathrm{C}$ are considered El Niño years, and values between -0.5 and $0.5^{\circ} \mathrm{C}$ are considered Neutral years (NOAA 2019).

\subsection{Statistical analyses}

First, we applied a joint analysis considering the 121 weather stations for accumulated rainfalls and temperatures. Then, to confirm the findings obtained in the joint analysis, we disaggregated the weather stations based on the mega-regions of the State of Goiás 
(Center, East, Northeast, North, and South) (Figure 1A) and applied the same statistical analysis (described below in section 2.5) for each mega-region. Table 1 shows the number of years (\#years), weather stations (\# WS) and seasons (curves) for the joint analysis (in all Goiás State) and mega-region analysis (disaggregated analysis in the Center, East, Northeast, North, and South sectors of Goiás State) for the three phases of ENSO phenomenon, for the three investigated periods and climate variables (accumulated rainfall; maximum and minimum temperature).

\subsubsection{Functional data analysis (FDA)}

We applied the functional data analysis (FDA) to determine the characteristics and quantify the dissimilarities among functional data of rainfalls and temperatures in the three periods investigated (1980-1989, 1990-1999, and 2000-2011) in the three phases of ENSO. Conceptually, functional data is continuously defined (Ramsay and Silverman 2002) despite being collected in a discrete way, that is, the term "functional" refers to the intrinsic structure of data and not to their form as manifested in observation. In formal terms, the functional record for each individual is defined by $p \in \mathbb{N}^{*}$ pairs $\left(t_{j}, y_{j}\right)$, where $y_{j}$ is an observation of a $x$ realization in $t_{j}$ and $j=$ $(1, \ldots, p)$. Therefore, it is possible to establish a functional relationship through the model $y_{j}=x\left(t_{j}\right)+\varepsilon_{j}$ in which the noise comes from the measurement process that contributes to the non-smoothness of the observed data $\boldsymbol{y}=\left(y_{1}, \ldots, y_{p}\right)$. The use of smoothing techniques allows knowing the function $x$ in its true functional form, which in turn allows its evaluation at point t. Non-parametric modeling, as a smoothing technique, is characterized by greater flexibility in the estimation of $x(t)$ since, a priori, it does not consider any type of distribution or trend that associates the independent variable $t_{j}$ with the response variable $y_{j}$. Thus, using discrete 
observations, the estimation of the function $x(t)$ is performed through a linear combination given by:

$$
\hat{x}(t)=\sum_{j=1}^{p} S_{j}(t) y_{j}
$$

The most common smoothing methods to represent the function as a linear combination of base functions are B-splines, Fourier, and others (Ramsay and Silverman 2005), or even local weighting: Kernel smoothing and local linear regression (Degras 2011; Loader 2012).

The functional data analysis (FDA) results for each ENSO phenomenon phase (La Niña, El Niño, and Neutral) across the periods (1980-1989, 1990-1999, and 2000-2011), hereafter called mean functional estimation (MFE), is the smoothed average curve that represent the set of number of season curves.

\subsubsection{Analysis of variance for functional data (FANOVA)}

The $n=n_{1}+\cdots+n_{l}$, the functional mean for a sample containing functions at fixed points, is given by

$$
\mu_{g j}(t)=\frac{1}{n_{g}} \sum_{i=1}^{n_{g}} X_{g i j}(t)
$$

where $X_{g i j}(t)$ is the $\mathrm{i}$-th function for $g=1, \ldots, l$ and $i=1, \ldots, n_{g}$, represents groups of independent random functions defined on the closed interval $T=[a, b]$. In the functional context there is an interest in testing the equality between two or more mean functions of different groups $H_{0}: \mu_{1}(t)=\mu_{2}(t)=\cdots=\mu_{l}(t)$. This technique is known as unidirectional functional variance analysis for functional data or FANOVA (Górecki and Smaga 2019). 
As described and demonstrated in Górecki and Smaga (2019), the stochastic process $X_{g i}(t)$, representing the $\mathrm{i}$-th function of the group, can be represented by base functions in such a way that it is possible to establish a test statistic (FP test) that compares the variance ratio between groups (deviation between the estimated mean functions of the groups and the general estimated mean function) and the variance within groups (deviations between the observed curves and the estimated mean function of the corresponding group). In addition, a $p$-value associated with this statistic is obtained through a permutation test, resulting in the functional variance defined as FP test (Górecki and Smaga 2015, 2019).

\subsubsection{Simultaneous confidence bands (SCB)}

In the context of functional data, constructing confidence bands separately for each point of the mean function, $u(t), t \in \mathbf{T}$, at a confidence level $1-\alpha$, produces inferences with a lower confidence level than the established one. For this reason, it is sought to make inferences by simultaneously evaluating the entire domain of the functional parameter represented by $\mathbf{T}=[a, b]$. Degras (2011) established from the result of an asymptotic normality $(n, p \rightarrow \infty)$ the construction of simultaneous confidence bands (SCB) for the mean function $\mu(t)$ at a confidence level $1-\alpha$, considering that:

$\lim _{n, p \rightarrow \infty} P\left(\hat{\mu}(t)-z_{\alpha, \rho} \frac{\hat{\sigma}}{\sqrt{n}} \leq \mu(t) \leq \hat{\mu}(t)+z_{\alpha, \rho} \frac{\hat{\sigma}}{\sqrt{n}}, t \in \theta\right)=1-$

$\alpha$

where $\hat{\mu}(t)$ is the mean function estimated by local weighting, $\sigma$ and $\rho$ are the function of variance and the correlation with estimates performed by principal functional component analysis, $z_{\alpha, \rho}$ is the quantile corresponding to the level of 
asymptotic confidence $1-\alpha$ obtained by numerical methods and, $\theta$ is a limited range $[0,1]$ (Degras 2011, 2017).

The SCB, in addition to producing a test statistic, has a direct application to test $H_{0}: \mu=\mu_{0}$ or $H_{0}: \mu_{1}-\mu_{2}=0$ hypotheses (Degras 2011, 2017). Thus, $H_{0}$ will be rejected if the simultaneous confidence level interval $1-\alpha$ does not contain $\mu_{0}$, where $\mu_{0}$ is a pre-specified function, or if $\mu_{2}$ is not centered on the simultaneous confidence interval of $\mu_{1}$

For the FDA, we applied the R packages fda (Ramsay et al. 2020) and fdANOVA (Górecki and Smaga 2018).

\section{Results and discussion}

\subsection{Joint analysis (entire Goiás State)}

As already explained in item 2.2.1, we performed a joint analysis of FDA considering the 121 weather stations for accumulated rainfalls and temperatures to determine the characteristics and quantify the dissimilarities in rainfall and temperature data time series in three periods (1980-1989, 1990-1999, and 2000-2011) under three different phases of the El Niño Southern Oscillation (ENSO) phenomenon in Central Brazil.

\subsubsection{Accumulated Rainfall}

Figure 2 shows the exploratory analysis of accumulated rainfall data. The median curve (level 0\%. Figure 2) for accumulated rainfall has similar characteristics regardless of the ENSO phenomenon phase and the investigated time period. For the first period (1980-1989), the highest accumulated rainfall value (last week of March) for the median curve (level 0\% in Figure 2) was for El Niño conditions (warm ENSO phase). However, for the other periods (1990-1999 and 2000-2011), the highest 
accumulated rainfall value (last week of march) for the median curve (level 0\% in Figure 2) occurred in La Niña and Neutral conditions. Mainly for Neutral conditions, we also observed a decrease in variability during the 2000-2011 period.

Figure 3 shows the MFE (mean functional estimation) and its SCB (simultaneous confidence bands) describing the characteristics of accumulated rainfall in the three phases of the ENSO phenomenon across the three investigated periods. For the first period (1980-1989), Neutral conditions revealed the highest rainfall accumulation from the first week of November until the end of January compared to El Niño and La Niña conditions. The first $500 \mathrm{~mm}$ accumulation happened a week earlier $\left(2^{\text {nd }}\right.$ week of December) for Neutral conditions than for the other ENSO phases $\left(3^{\text {rd }}\right.$ week of December for El Niña and El Niño). However, this was not noticed for the other periods (1990-1999 and 2000-2011). In fact, during these two periods of rainfall accumulation in El Niño and La Niña conditions, there were similar characteristics. Although the FANOVA test does not discriminate statistical differences among MFE $(\mu$-ElNino $/ \mu$-LaNina $/ \mu$-Neutro are not similar $-p$-values $<0.05$, Table 2$)$ for ENSO phenomena across the different investigated periods, there is a decrease in the FP test values in these periods. This is an indication that ENSO phenomena tend to show similar accumulated rainfall characteristics. Similar characteristics also happened when applying the SCB hypothesis test between two MFEs (Table 3 $\mu$-ElNino/ $\mu$-LaNina; $\mu$-ElNino/ $\mu$-LaNina; $\mu$-LaNina/ $\mu$-Neutro). Although MFEs were statistically different (Table 3, p-value $<0.05$ ), there was an important reduction in the values of the test statistic SCB from 1980-1989 to 2000-2011. Graphically, we also noticed that for the most recent periods, the MFEs for the three ENSO phases tend to show similar accumulated rainfall characteristics (Figure S2 - supplementary information). To emphasize this feature over the three investigated periods, we 
calculated the values of the difference (in absolute value) among MFEs for ENSO phenomena (El Niño - La Niña; El Niño - Neutral, and La Niña - Neutral) for each period (Figure 4). For the first period (1980-1989), the highest accumulated rainfall variation happened between the end of November to the end of January. In this period, the highest difference in accumulated rainfall was for La Niña - Neutral, followed by El Niño - La Niña. In this period, the highest difference $(\sim 175 \mathrm{~mm})$ occurred at the beginning of January (Figure 4). For the second period (1990-1999), the highest accumulated rainfall variation also happened in this same period, from the end of November to the end of January. However, in this period, the highest difference ( $150 \mathrm{~mm}$ ) in accumulated rainfall was for El Niño - Neutral, followed by El Niño - La Niña. We also noticed that in this period (1990-1999), by the absolute differences (Figure 4), that El Ninõ/Neutral and El Ninõ/La Ninã had a similar pattern. The statistic test based on the SCB (Table 3, a) Prec) also supports the similarity for $\mu$-ElNino/ $\mu$-LaNina (10.03 Statistic test value) and $\mu$-ElNino/ $\mu$-Neutral $(10.03$ Statistic test value). We did not notice the same similarity for the first period analyzed (1980-1989). For the 2000-2011 period, we did not observed a specific period of highest accumulated rainfall. In this period, the highest difference $(\sim 50 \mathrm{~mm})$ also occurred in the middle of November. In this period, there is a clear similarity in the characteristics for ENSO phenomena in accumulated rainfalls (Figure 3 and 4, 2000-2011 period).

In practical terms, during the 1980-1989 period the accumulation of $500 \mathrm{~mm}$ would be reached around the third week of December in Neutral conditions. Under the effects of the other ENSO conditions (El Niño and La Niña), this amount would be achieved around the fifth week of November. On the other hand, for the other two periods (1990-1999 and 2000-2011), $500 \mathrm{~mm}$ would be achieved around the fourth 
week of December regardless of ENSO conditions. In other words, the number of days, on average, for accumulated $500 \mathrm{~mm}$ across periods (1980-1989, 1990-1999, and 2000-2011) were 82, 86, and 80, respectively (Table 4b). We observed a decrease in the variation of standard deviation in the periods (1980-1989, 1990-1999, and 2000-2011). This decrease in standard deviation (SD) was marked from 1990-1999 to 2000-2011 (Table 4b). According to Heinemann et al. (2021), in the study region a total rainfall volume of $43 \mathrm{~mm}$ is sufficient to bring the first layer $(\sim 17 \mathrm{~cm})$ of soil to field capacity to sow crops. The number of days, in average, for the begin of crop season in the periods (1980-1989, 1990-1999, and 2000-2011) were 14, 16, and 14.7, respectively (Table 4a). Here, we noticed the same feature for accumulated $500 \mathrm{~mm}$, i.e., a decrease in the standard deviation, mainly from 1990-1999 to 2000-2011. These observations (accumulated $500 \mathrm{~mm}$ and beginning of crop season) corroborate the results obtained in this study, where we observed an increasing similarity among the three investigated ENSO phenomena phases, being more evident in the last period (2000-2010) (Table 4).

\subsubsection{Maximum temperature}

Figure 5 shows the exploratory analysis of maximum temperature. The highest maximum temperature values for the median curve (level 0\%, Figure 5) were concentrated in October. This month is characterized by a transition between dry and wet season in the study region. There is an increase in the occurrence of high maximum temperature peaks $(>=40 \mathrm{C})$ and also a reduction in the variability of maximum temperature values in the last period (2000-2011) (Figure 5). This reduction in variability is mainly due to an increase in maximum temperature values observed in the last period. 
Figure 6 shows the MFEs and their SCB describing the patterns of maximum temperature under different ENSO conditions across the three investigated periods.

We observed an increase in the maximum temperature values for October across decades for all ENSO conditions. For the first period (1980-1989), the MFEs did not show maximum temperature values equal or higher than $35^{\circ} \mathrm{C}$ for October. However, for the second (1990-1999) and third (2000-2011) periods, we observed values higher than or equal to $35^{\circ} \mathrm{C}$ for El Niño (in the beginning of October, 1990-1999), La Niña (in the middle of October and beginning of November, 1990-1999), El Niño (in the beginning of October, 2000-2011), La Niña (in the middle of October, 2000-2011), and Neutral (end of October, 2000-2011) (Figure 6). The MFEs also showed an increase in maximum temperature values throughout the rainfed season (October to March) for all ENSO conditions and investigated periods. The warning trend observed in this study by an increase in maximum temperature values can jeopardize future demands for increased crop production in the region. Furthermore, it has been estimated that for each degree Celsius $\left({ }^{\circ} \mathrm{C}\right)$ increase in global mean temperature, crop yield will reduce by $6 \%$ (wheat), $10-12 \%$ (rice), or $3 \%$ (soybean), thus affecting global food security (Nelson et al., 2010; Asseng et al., 2015; Zhao et al., 2017). In the first period (1980-1989), at the end of November, there was the occurrence of the highest maximum temperature value $\left(33^{\circ} \mathrm{C}\right)$. In the second period (1990-1999), mainly under La Niña conditions, it is quite common from middle of January to middle of February to show maximum temperatures equal to $33^{\circ} \mathrm{C}$. The last period (2000-2011) also shows values of maximum temperature equal to $33^{\circ} \mathrm{C}$, mainly in El Niño conditions. We also observed a decrease in the occurrence of maximum temperature values below $31^{\circ} \mathrm{C}$ across the three investigated periods for all ENSO conditions. There is a pattern for increasing maximum temperatures values across 
decades in all ENSO conditions. Although the FANOVA test did not discriminate statistical differences among the MFEs (Table 2, $p$-value $<0.05$ for joint analysis), we observed that FP test values decreased from the first to the last investigated period (from 49.54 to 23.30, Table 2, FP test for Tmax). This indicates that the MFE for maximum temperature under La Niña, El Niño, and Neutral conditions tend to be similar during the last investigated period. However, for maximum temperature, this feature is not as strong as previously noticed for accumulated rainfalls.

When we applied the SCB hypothesis test between two MFE for maximum temperature (Table 3b, Tmax - $\mu$-ElNino/ $\mu$-LaNina; $\mu$-ElNino/ $\mu$-Neutral; $\mu$-LaNina/ $\mu$-Neutral), despite $p$-values not showing similarity among ENSO MFEs in each investigated period, we observed a decrease of statistical test values (Table $3 b$ ) from the first to the last period. This decrease is not marked as that observed for accumulated rainfalls but it is also an indicator that these features under ENSO conditions tend to be similar during the last investigated period. Although the values of statistical test decreased from the first to the last investigated period, we observed for the second period (1990-1999) an increase in statistical test values. Graphically, we noticed that the second period showed the highest difference between ENSO conditions and the last period showed the highest similarity (Supplementary Figure $3 S)$.

Although the MFEs are statistically different (Table 3, p-value,$<0.05)$, there is a significant reduction in the values of test statistic SCB in the periods from 1980-1989 to 2000-2011. Graphically, we also noticed that increases are a trend in MFEs for ENSO conditions and show similar patterns for maximum temperature (Figure S3 supplementary information). To emphasize this trend over the periods, we calculated (absolute values) the difference among MFEs for ENSO phenomena (El Niño - La 
Niña; El Niño - Neutral and La Niña - Neutral) for each period (Figure 7). The variability decreased for maximum temperature values for all ENSO conditions from the first to the last period (about $1{ }^{\circ} \mathrm{C}$ ). The highest differences among El Niño, La Niña, and Neutral MFE occurred for the first and second periods (1980-1989 and 1990 to 1999 ) (around $2.5^{\circ} \mathrm{C}$ ). For the last period (2000-2011), the highest difference among ENSO phenomena was around $1.5^{\circ} \mathrm{C}$. This is also an indicator that El Niño, La Niña, and Neutral MFE are similar in the last investigated period.

\subsubsection{Minimum temperature}

Figure 8 shows the exploratory analysis of the minimum temperature data set. The median curve (level 0\%) under El Niño conditions shows the highest values of minimum temperature for all investigated periods. On the other hand, under La Niña conditions, the median curve (level $0 \%$ ) shows the lowest values of minimum temperature.

Figure 9 shows the MFEs and their SCB, which describe the patterns of minimum temperature for ENSO conditions across the three investigated periods. The values of minimum temperature increased in the second and third periods, as shown by MFEs for all ENSO conditions (Figure 9). The coldest week was the first week of October, with a minimum temperature of around 17 and $17.5^{\circ} \mathrm{C}$ in the first period (1980-1989) for all ENSO conditions. For the second period (1990 to 1999), we observed an increase in the minimum temperature values mainly for the MFEs under La Niña $\left(18.5^{\circ} \mathrm{C}\right)$ and $\mathrm{El}$ Niño $\left(18^{\circ} \mathrm{C}\right)$ conditions for the first week of October. In the third period (2000-2011), we observed the highest increase in minimum temperature values for the first week of October for all MFE ENSO conditions. In this period, the lowest temperature value for the first week of October was around $18.5^{\circ} \mathrm{C}$, an increase of 
about $1.5^{\circ} \mathrm{C}$. For the first period, the highest minimum temperature values were observed from December to the end of January for the MFEs under El Niño conditions, with values around $19.5^{\circ} \mathrm{C}$. For the second period, the highest minimum temperature values occurred in the second week of November $\left(19.5^{\circ} \mathrm{C}\right)$ and the beginning of February $\left(20.0^{\circ} \mathrm{C}\right)$ for MFEs under El Niño conditions, and middle of November $\left(19.5^{\circ} \mathrm{C}\right)$ for La Niña conditions. The third period was a larger period for higher minimum temperature values from December to middle of January for El Niño conditions MFEs peaking around $20^{\circ} \mathrm{C}$. It is clear that values of minimum temperature increased across the three investigated periods in all ENSO conditions (Figure 9). The FANOVA test did not discriminate statistical differences among MFEs (Table 2, $p$-value $<0.05$ for joint analysis) for minimum temperature across the three investigated periods. Contrary to that observed for accumulated rainfalls and maximum temperatures, FP test values increased from the first to the last period (20.42, 37.77 and 49.93, Table 2, FP test for Tmin). This indicates an increase in dissimilarity among the minimum temperature MFEs under La Niña, El Niño, and Neutral in the investigated periods.

When we applied the SCB hypothesis test between two MFEs for minimum temperature (Table 3c, Tmin - $\mu$-ElNino/ $\mu$-LaNina; $\mu$-ElNino/ $\mu$-Neutral; $\mu$-LaNina/ $\mu$-Neutral), $p$-values did not show similarity among ENSO MFEs in each investigated period. The statistical test values (Table 3c) for $\mu$-ElNino $/ \mu$-LaNina increased from first (1980-1989) to last (2000-2011) period, showing dissimilarity between El Niño and La Niña conditions. However, comparing the MFE La Niña and El Niño with Neutral conditions, we observed that the values of the statistical test decreased from the first to the last period mainly for $\mu$-ElNino/ $\mu$-Neutral (Table 3c). Graphically, we noticed for the last period a decrease in the similarity of MFE 
characteristics between El Niño and La Niña conditions and an increase in similarity between MFE characteristics among Neutral and La Niña and El Niño conditions (Supplementary Figure S4). We also noticed that MFE for La Niña conditions had higher minimum temperature values than for Neutral conditions during the last period (Supplementary Figure S4). We calculated the absolute values of the difference among MFEs under ENSO conditions (El Niño - La Niña; El Niño - Neutral and La Niña - Neutral) for minimum temperature for each period (Figure 7). The highest variability among ENSO conditions MFE occurred during the second period investigated. This period showed the highest dissimilarity among MFEs. On the other hand, the first period showed the lowest variability among MFEs.

In practical terms, we observed an increase in the values of minimum temperature across the three investigated periods. This increase was marked in the beginning of the rainfed season (October) under El Niño and Neutral conditions.

\subsection{Disaggregated analysis (mega-regions)}

We disaggregated weather stations' data into five mega-regions (Center, East, Northeast, North, and South) in the study area, as described in section 2.2.1 (Figure 1A). Table 1 shows the number of years (\#years), weather stations (\# WS), and season curves for mega-regions analyzed (disaggregated analysis).

\subsubsection{Disaggregated accumulated rainfall}

Figure 11 shows the MFEs and their SCB (simultaneous confidence bands) describing the characteristics of accumulated rainfall under different ENSO conditions across the three investigated periods for all mega-regions (Center, East, Northeast, North, and South). According to the FANOVA test, only the mega-region East discriminates statistical difference among MFE under ENSO conditions 
$(\mu$-ElNino $/ \mu$-LaNina/ $\mu$-Neutro are similar, $p$-value $=0.106$, Table $2 \mathrm{a})$ during the last period (2000-2011). For the East mega-region in the 2000-2011 period, La Niña, El Niño, and Neutral conditions showed a similar behavior. For the other mega-regions (Center, North and Northeast), although the FANOVA test does not discriminate statistical difference among MFEs ( $\mu$-ElNino/ $\mu$-LaNina/ $\mu$-Neutro are not similar $p$-values $<0.05$, Table $2 \mathrm{a}$ ) under ENSO conditions in the investigated periods, we observed a decrease in the FP test values towards later periods. This indicates that ENSO conditions tend to have similar impacts on accumulated rainfall characteristics towards most recent periods. This feature also occurred in joint accumulated rainfall analyses (for the entire Goiás State), as discussed earlier in section 3.1.1. Only for Center and South regions was there an increase in FP test values from the first to the second investigated period (Table 2a), not following the same behavior as that noticed in joint analyses for accumulated rainfall (joint analysis or entire Goiás, item 3.1.1). However, for the second to the third period (1990-1999 and 2000-2011), all mega-regions showed the same behavior as in the joint analysis, i.e., a decrease in FP test values (Table 2a), indicating similarity in all ENSO conditions.

\subsubsection{Disaggregated maximum temperature}

Figure 12 shows the MFEs and their SCB describing maximum temperature characteristics in different ENSO conditions across the three investigate periods for all mega-regions (Center, East, Northeast, North, and South). For all mega-regions, we observed an increase in maximum temperature values during the last period (2000-2011) in the investigated season (October to March) under all ENSO conditions (Figure 12). Although the FANOVA test does not discriminate statistical differences among MFEs ( $\mu$-EINino $/ \mu$-LaNina $/ \mu$-Neutro are not similar $-p$-values $<0.05$, Table b) for different ENSO conditions in the three investigated periods, for all 
mega-regions there was a decrease in the FP test values from the first to the third period. This indicates that the MFEs for maximum temperature under La Niña, El Niño, and Neutral conditions in all mega-regions tend to be similar during the last period (2000-2011). This feature was also identified in joint analyses (for the entire Goiás State) for maximum temperatures in the most recent period (2000-2011) (section 3.1.2).

\subsubsection{Disaggregated minimum temperature}

Figure 13 shows the MFEs and their SCB describing maximum temperature characteristics under different ENSO conditions in the three investigated periods for all mega-regions (Center, East, Northeast, North, and South). For all mega-regions we observed an increase in the values of minimum temperatures in the second and third periods, as shown by the MFEs in all ENSO conditions (Figure 13). The same feature occurred in joint analyses (for the entire Goiás State) for minimum temperature (Figure 9). FANOVA test does not discriminate statistical differences among MFEs ( $\mu$-ElNino/ $\mu$-LaNina $/ \mu$-Neutro are not similar - $p$-values $<0.05$, Table $2 \mathrm{c})$ for different ENSO conditions in the three investigated periods for Center, North, Northeast, and South mega-regions. Only for the East mega-region, during the first and third periods, MFEs under all ENSO conditions are statistically similar ( $\mathrm{p}$ value > 0.05, table 2c). This indicates a similar behavior in all ENSO conditions during the first and third investigated periods. This mega-region is an exception and shows a different behavior as that previously identified in joint analyses (for the entire Goiás State, section 3.1.3). However, for the Center, North, and South mega-regions, we observed that FP test values increased from the first to the last investigated period (Table 2c). This indicates an increase in dissimilarity among the MFEs of minimum temperature under La Niña, El Niño, and Neutral conditions during the first to third 
periods in these mega-regions. This is the same feature as previously noticed in joint analyses (for the entire Goiás State) for minimum temperatures (section 3.1.3).

Contrary to Center, North, and South mega-regions, the Northeast mega-region shows an opposite behavior, with a decrease in FP test values from the first and the third period. For the Northeast mega-region, the characteristic is similar across different ENSO conditions during the last period.

\section{Conclusion}

This study diagnoses the behavior of temperature and rainfall time series of 128 weather stations across the Goiás State in Brazil over three periods (1980-1989, 1990-1999, and 2000-2011) under El Niño, Neutral, and La Niña conditions. The analysis revealed no major impacts of ENSO conditions on accumulated rainfall characteristics, a feature particularly marked in the most recent period (2000-2011). This was observed both for the entire Goiás state and for the State mega-regions.

ENSO affect maximum temperature considering the entire State mainly in the first two periods. There was an increase in maximum temperature values throughout the rainfed season (October to March) under all ENSO conditions and investigated periods. The same behavior was noticed for all mega-regions.

ENSO affects minimum temperatures but presented a considerable variability across the investigated periods, which increased from first to the last period. This feature was observed both for the entire Goiás State and for the State mega-regions, with the exception of the East and Northeast mega-regions. There was an increase in the values of minimum temperature across the three investigated periods. This increase was marked in the beginning of the rainfed season (October) under El Niño and Neutral conditions. 


\section{Acknowledgments}

AB Heinemann acknowledges the support from "Fundação de Amparo à Pesquisa do Estado de Goiás” (FAPEG -PRONEM/FAPEG/CNPq) and “Conselho Nacional de Desenvolvimento Científico e Tecnológico" (CNPq -Edital Universal -Processo -408025/2018-2. CASC thanks the support from CNPq, process no. 305206/2019-2.

\section{References:}

Abrahão, G.M. and Costa, M.H. (2018) Evolution of rain and photoperiod limitations on the soybean growing season in Brazil: The rise (and possible fall) of double-cropping systems. Agricultural and Forest Meteorology, 256-257, 32-45. https://doi.org/10.1016/j.agrformet.2018.02.031

Alvares, C.A., Stape, J.L., Sentelhas, P.C., Gonçalves, J.L.M. and Sparovek, G. (2013) Koppen's climate classification map for Brazil. Meteorologische Zeitschrift, 22, 711728. https://doi.org/ 10.1127/0941-2948/2013/0507

Andreoli RV, Kayano MT (2006) Tropical Pacific and South Atlantic effects on rainfall variability over Northeast Brazil. Int J Climatol 26:1895-1912. https://doi.org/10.1002/joc.1341

Asseng S, Ewert F, Martre P et al (2015) Rising temperatures reduce global wheat production. Nat Clim Change 5:143-147. https://doi.org/10.1038/nclimate2470

Bhuvaneswari, K., Geethalakshmi, V., Lakshmanan, A., Srinivasan, R. and Sekhar, U.N. (2013) The impact of El Niño/Southern oscillation on hydrology and rice productivity in the Cauvery Basin, India: application of the soil and water assessment tool. Weather and Climate Extremes, 2, 39-47.

Degras D (2011) Simultaneous confidence bands for nonparametric regression with functional data. Stat Sin 21: 1735-1765. http://dx.doi.org/10.5705/ss.2009.207 
Acompanhamento da Safra Brasileira de Grãos, Brasília, DF, v. 8, safra 2020/21, n. 6, sexto levantamento, mar. 2021. Available at: http://www.conab.gov.br.

Degras D (2017) Simultaneous confidence bands for the mean of functional data. Wiley

Górecki T, Smaga L (2015) A comparison of tests for the one-way ANOVA problem

data.

Comput

Stat

30:987-1010.

544

545

546

https://doi.org/10.1007/s00180-015-0555-0

Górecki T, Smaga L (2018) fdANOVA: analysis of variance for univariate and $\begin{array}{lllll}\text { multivariate functional data. } & \mathrm{R} \text {. package version }\end{array}$ https://CRAN.R-project.org/package=fdANOVA

Górecki T, Smaga L (2019) fdANOVA: an R software package for analysis of variance for univariate and multivariate functional data. Comput Stat 34:571-597. https://doi.org/10.1007/s00180-018-0842-7

Grimm AM (2003) The El Niño impact on the summer monsoon in Brazil: regional processes versus remote influences. J Clim 16:263-280. https://doi.org/10.1175/1520-0442(2003)016<0263:TENIOT>2.0.CO;2

Grimm AM, Tedeschi RG (2009) ENSO and extreme rainfall events in South America. J Clim 22:1589-1609. https://doi.org/10.1175/2008JCLI2429.1

Heinemann, AB., Ramirez-Villegas, J., Rebolledo, MC., Costa Neto, GMF. and Castro, AP. (2019) Upland rice breeding led to increased drought sensitivity in Brazil. Field Crops Research, 231, 57-67. https://doi.org/10.1016/j.fcr.2018.11.009 Heinemann AB, RamirezVillegas J, Stone LF et al (2021) The impact of El Niño Southern oscillation on cropping season rainfall variability across Central Brazil. Int $\mathbf{J}$ Climatol. 41:E283-E304. https://doi.org/10.1002/joc.6684 
IBGE (2020). Área territorial oficial. Rio de Janeiro: Intituto Brasileiro de Geografia e Estatística. Available at https://www.ibge.gov.br/cidades-e-estados. Access at June 2021.

Iizumi T, Ramankutty N (2015) How do weather and climate influence cropping area and intensity? Global Food Secur 4:46-50. https://doi.org/10.1016/j.gfs.2014.11.003 Kayano MT, Andreoli RV, Souza RAF (2013) Relations between ENSO and the South Atlantic SST modes and their effects on the South American rainfall. Int J Climatol 33:2008-2023. https://doi.org/10.1002/joc.3569

Loader C (2012) Smoothing: local regression techniques. In: Gentle JE, Härdle WK, Mori Y (eds) Handbook of Computational Statistics: concepts and methods, Springer, Berlin, pp 571-596. https://doi.org/10.1007/978-3-642-21551-3_20

Moura MM, Santos AR, Pezzopane JEM et al (2019) Relation of El Niño and La Niña phenomena to precipitation, evapotranspiration and temperature in the Amazon basin. Sci Total Environ 651:1639-1651. https://doi.org/10.1016/j.scitotenv.2018.09.242

Nelson GC, Rosegrant MW, Palazzo A et al (2010) Food security, farming, and climate change to 2050: scenarios, results, policy options. Internatinal Food Policy Research Institute, Washington. http://dx.doi.org/10.2499/9780896291867

Nóia Júnior RS, Sentelhas PC (2019) Soybean-maize succession in Brazil: impacts of sowing dates on climate variability, yield and economic profitability Eur J Agron 103: 140-151. https://doi.org/10.1016/j.eja.2018.12.008

NOAA. 2019. Historical ENSO episodes (1950-present): Cold and warm episodes by 791 season. National Weather Service, Climate Prediction Center. Available at: http://www.cpc.ncep.noaa.gov/products/analysis_monitoring/ensostuff/ensoyears_ER SSTv3b.shtml. 
Penalba OC, Rivera JA (2016) Precipitation response to El Niño/La Niña events in southern South America - emphasis in regional drought occurrences. Adv Geosci 42:1-14. https://doi.org/10.5194/adgeo-42-1-2016

Pereira Júnior LC, Nicácio PP (2015) Demanda hídrica para irrigação por pivôs centrais no estado de Goiás. Boletim Goiano de Geografia 34:443-463. https://doi.org/10.5216/bgg.v34i3.33855

Prado LF, Wainer I, Yokoyama E et al (2021) Changes in summer precipitation variability in central Brazil over the past eight decades. Int J Climatol 41:4171-4186. https://doi.org/10.1002/joc.7065

PBMC Painel Brasileiro de Mudanças Climáticas. (2014) Impactos, vulnerabilidades e adaptação às mudanças climáticas: primeiro relatório de avaliação nacional. COPPE. Universidade Federal do Rio de Janeiro, Rio de Janeiro, RJ, Brasil, (http://www.pbmc.coppe.ufrj.br/pt/publicacoes/relatorios-pbmc/item/impactosvulnerabilidades-e-adaptacao-volume-2-completo)

Ramirez-Villegas, J. and Challinor, A. (2012) Assessing relevant climate data for agricultural applications. Agricultural and Forest Meteorology, 161, 26-45. $\underline{\text { https://doi.org/10.1016/j.agrformet.2012.03.015 }}$

Ramirez-Villegas, J., Heinemann, A.B., Castro, A.P., Breseghello, F., Navarro-Racines, C., Li, T., Rebolledo, M.C. and Challinor, A.J. (2018) Breeding implications of drought stress under future climate for upland rice in Brazil. Global Change Biology, 24, 2035-2050. https://doi.org/10.1111/gcb.14071

Ramsay JO, Silverman BW (2002) Introduction. In: Ramsay JO, Silverman BW (eds) Applied Functional Data Analysis: methods and case studies. Springer, New York, pp 1-16. https://doi.org/10.1007/978-0-387-22465-7_1 
610 Ramsay JO, Silverman BW (2005) Functional data analysis, $2^{\text {nd }}$ edn. Springer, New

611

612

613 York. https://doi.org/10.1007/b98888

Ramsay JO, Graves S, Hooker G (2020). fda: Functional Data Analysis. R package version 5.1.9. https://CRAN.R-project.org/package=fda

Santos EB, Freitas ED, Rafee SAA et al (2021) Spatio- temporal variability of wet and drought events in the Paraná River basin-Brazil and its association with the El Niño-Southern oscillation phenomenon. Int J Climatol. https://doi.org/10.1002/joc.7104

Silva BES, Farias PHS, Stone LF et al (2018) Tendência e projeção da temperatura do ar para o Estado de Goiás. Embrapa Arroz e Feijão, Santo Antônio de Goiás. Embrapa Arroz e Feijão. http://www.infoteca.cnptia.embrapa.br/infoteca/handle/doc/1088274 Souza IP, Andreoli RV, Kayano MT et al (2021) Seasonal precipitation variability modes over South America associated to El Niño-Southern Oscillation (ENSO) and non-ENSO components during the 1951-2016 period. Int J Climatol 41:4321-4338. https://doi.org/10.1002/joc.7075

Verburg, R., Rodrigues Filho, S., Lindoso, D.P., Debortoli, N., Litre, G. and Bursztyn, M. (2014a) The impact of commodity price and conservation policy scenarios on deforestation and agricultural land use in a frontier area within the Amazon. Land Use Policy 37, 14-26. https://doi.org/10.1016/j.landusepol.2012.10.003

Verburg, R., Rodrigues Filho, S., Debortoli, N., Lindoso, D.P., Nesheim, I. and Bursztyn, M. (2014b) Evaluating sustainability options in an agricultural frontier of the Amazon using multi-criteria analysis. Land Use Policy 37, 27-39. 854 https://doi.org/10.1016/j.landusepol.2012.12.005 
633 Van Wart, J., Grassini, P., Yang, H., Claessens, L., Jarvis, A. and Cassman, K.G. 634 (2015). Creating long-term weather data from thin air for crop simulation modeling. 635 Agricultural and Forest Meteorology, 209-210, 49-58.

636 Xavier, A. C., King, C. W., and Scanlon, B. R. (2016). Daily gridded meteorological 637 variables in Brazil (1980-2013). Int. J. Climatol. 36, 2644-2659. 638 doi:10.1002/joc. 4518

639 Zhao C, Liu B, Piao S et al (2017) Temperature increase reduces global yields of 640 major crops in four independent estimates. Proc Natl Acad Sci USA 114:9326-9331. 641 https://doi.org/10.1073/pnas.1701762114

642

643 


\section{Conflict of Interest}

The authors declare no competing interests.

\section{Funding Statement}

a) Alexandre Bryan Heinemann was supported by Fundação de Amparo à Pesquisa do Estado de Goiás (FAPEG), PRONEM/FAPEG/CNPq, and Conselho Nacional de Desenvolvimento Científico e Tecnológico (CNPq), no. 408025/2018-2

b) Caio Augusto dos Santos Coelho was supported by Conselho Nacional de Desenvolvimento Científico e Tecnológico (CNPq), no. 305206/2019-2.

\section{Author's Contribution}

Alexandre Bryan Heinemann and David Henriques da Matta conceived the theory;

Alexandre Bryan Heinemann and Leydson Lara dos Santos generated the dataset and performed the data analysis ; Alexandre Bryan Heinemann and David Henriques da Matta wrote the manuscript, Luis Fernando Stone and Caio Augusto dos Santos Coelho revised the text, figures and tables, which all the authors finally edited.

\section{Availability of data and material}

The observational data set analyzed in this study may be obtained through the following links:

\section{Brazilian Institute of Meteorology (INMET - https://portal.inmet.gov.br/);}

Water National Agency (ANA - https://www.gov.br/ana/pt-br),

Goiás Meteorological and Hydrological Information Center (CIMEHGO https://www.meioambiente.go.gov.br/cimehgo); and Brazilian Agricultural Research Corporation (EMBRAPA https://www.embrapa.br/). 
667

668

669

670

671

672

673

674

675

676

677

678

679

680

681

682

683

684

685

686

687

688

689

690

691

692

Code availability

The $\mathrm{R}$ code will be available (by the corresponding author) upon requests

\section{Ethics approval}

The authors confirm that this article is original research and has not been published or presented previously in any journal or conference in any language (in whole or in part).

\section{Consent for publication}

The authors declare that have consent to participate and consent to publish.

\section{Conflict of interest}

The authors declare no competing interests.

Author information

\section{Affiliations:}

Federal University of Goiás (UFG), Institute of Mathematics and Statistics (IME), Campus II -Av. Esperança, s/n Instituto de Matemática e Estatística, Samambaia, Goiânia GO, 74001-970

David Henriques da Matta; Leydson Lara dos Santos

Centro de Previsão de Tempo e Estudos Climáticos (CPTEC), Instituto Nacional de Pesquisas Espaciais (INPE), Rodovia Presidente Dutra, Km 40, SP-RJ,

Cachoeira Paulista, SP, 12630-000

Caio Augusto dos Santos Coelho

Embrapa Arroz e Feijão, Rodovia GO-462 km 12 Zona Rural, 75375-000 Santo Antônio de Goiás, GO, Brazil

Luis Fernando Stone; Alexandre Bryan Heinemann

Corresponding author:

Correspondence to Alexandre Bryan Heinemann 
Table 1. Number (\#) of years, weather stations (WS), and seasons curves for joint analysis (Goiás) and disaggregated analysis (Mega-regions) for ENSO conditions, investigated periods, and climate variables (Prec - rainfall; Tmax - maximum temperature, and Tmin - minimum temperature).

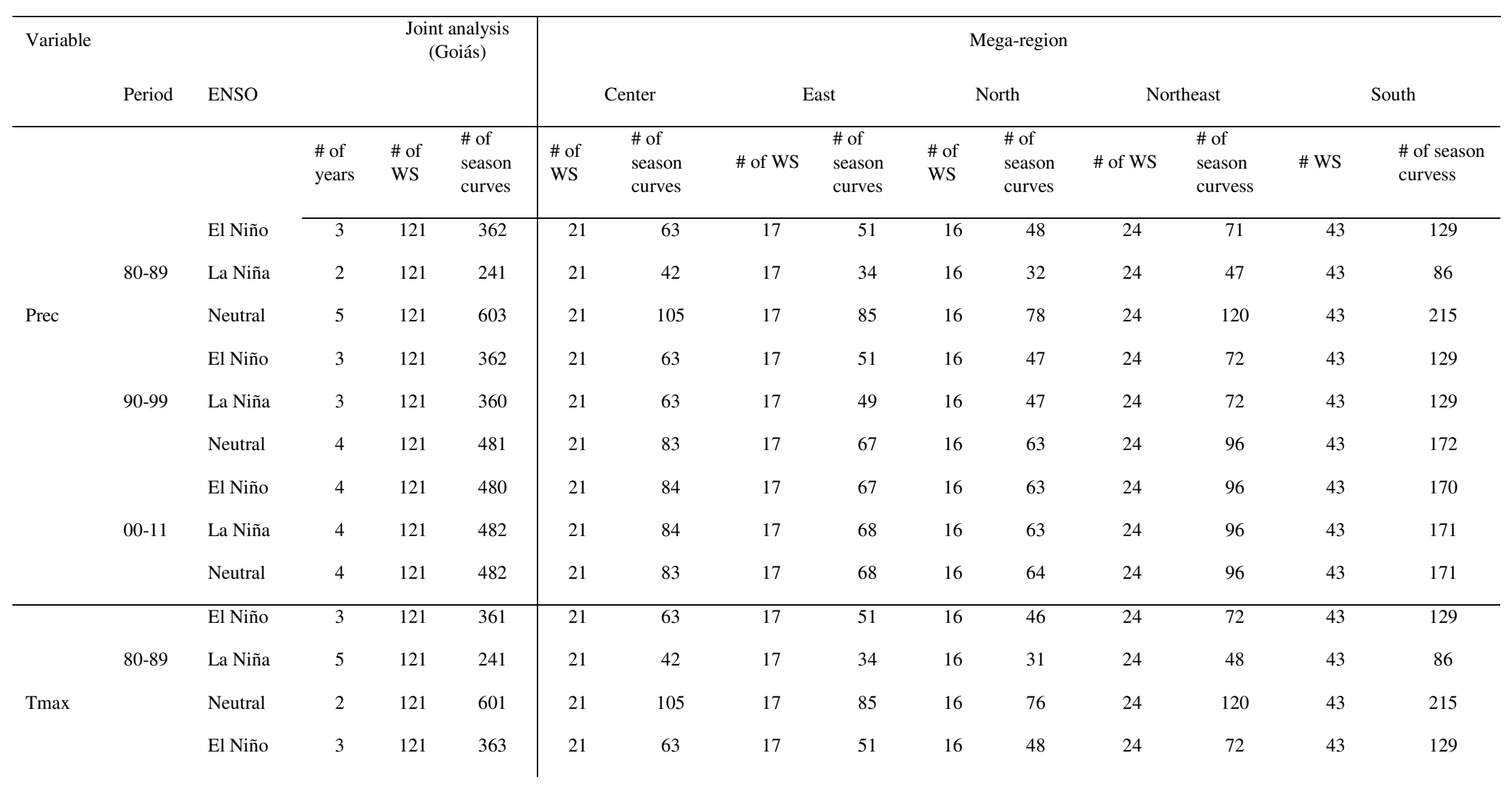




\begin{tabular}{|c|c|c|c|c|c|c|c|c|c|c|c|c|c|c|c|}
\hline & $90-99$ & La Niña & 3 & 121 & 363 & 21 & 63 & 17 & 51 & 16 & 48 & 24 & 72 & 43 & 129 \\
\hline & & Neutral & 4 & 121 & 484 & 21 & 84 & 17 & 68 & 16 & 64 & 24 & 96 & 43 & 172 \\
\hline & & El Niño & 4 & 121 & 484 & 21 & 84 & 17 & 68 & 16 & 64 & 24 & 96 & 43 & 172 \\
\hline & 00-11 & La Niña & 4 & 121 & 484 & 21 & 84 & 17 & 68 & 16 & 64 & 24 & 96 & 43 & 172 \\
\hline & & Neutral & 4 & 121 & 484 & 21 & 84 & 17 & 68 & 16 & 64 & 24 & 96 & 43 & 172 \\
\hline \multirow{9}{*}{ Tmin } & & El Niño & 3 & 121 & 361 & 21 & 63 & 17 & 51 & 16 & 46 & 24 & 72 & 43 & 129 \\
\hline & 80-89 & La Niña & 2 & 121 & 241 & 21 & 42 & 17 & 34 & 16 & 31 & 24 & 48 & 43 & 86 \\
\hline & & Neutral & 5 & 121 & 601 & 21 & 105 & 17 & 85 & 16 & 76 & 24 & 120 & 43 & 215 \\
\hline & & El Niño & 3 & 121 & 363 & 21 & 63 & 17 & 51 & 16 & 48 & 24 & 72 & 43 & 129 \\
\hline & 90-99 & La Niña & 3 & 121 & 363 & 21 & 63 & 17 & 51 & 16 & 48 & 24 & 72 & 43 & 129 \\
\hline & & Neutral & 4 & 121 & 484 & 21 & 84 & 17 & 68 & 16 & 64 & 24 & 96 & 43 & 172 \\
\hline & & El Niño & 4 & 121 & 479 & 21 & 84 & 17 & 68 & 16 & 59 & 24 & 96 & 43 & 172 \\
\hline & 00-11 & La Niña & 4 & 121 & 484 & 21 & 84 & 17 & 68 & 16 & 64 & 24 & 96 & 43 & 172 \\
\hline & & Neutral & 4 & 121 & 483 & 21 & 84 & 17 & 68 & 16 & 64 & 24 & 96 & 43 & 171 \\
\hline
\end{tabular}


Table 2. Functional analysis of variance (FANOVA) and permutation F test (FP test)

for the mean functional estimated for a) accumulated rainfall (Prec), b) maximum

temperature (Tmax), and c) minimum temperature (Tmin) in three investigated

periods for joint (Goiás) and mega-region (disaggregated) analysis considering all

estimated curves for ENSO conditions (El Niño, La Niña, and Neutral).

\begin{tabular}{|c|c|c|c|c|c|}
\hline & & & & Period & \\
\hline & & & 1980-1989 & 1990-1999 & $2000-2011$ \\
\hline & & & $\mu$-EINino $/ \mu$-LaNina/ $\mu$-Neutro & $\mu$-EINino $/ \mu$-LaNina/ $\mu$-Neutro & $\mu$-EINino/ $\mu$-LaNina/ $\mu$-Neutro \\
\hline & & & & Joint analysis (Goiás) & \\
\hline & & FP test & 24.82 & 17.62 & 8.80 \\
\hline & & $p$-value & 0.000 & 0.000 & 0.000 \\
\hline & & & & Mega-region analysis & \\
\hline & Center & FP test & 5.72 & 7.38 & 2.44 \\
\hline a) Prec & & p-value & 0.001 & 0.000 & 0.048 \\
\hline & East & FP test & 5.76 & 5.53 & 1.93 \\
\hline & & p-value & 0.002 & 0.001 & $0.106^{*}$ \\
\hline & North & FP test & 16.97 & 3.70 & 3.24 \\
\hline & & $p$-value & 0.000 & 0.015 & 0.023 \\
\hline & Northeast & FP test & 8.01 & 4.32 & 2.96 \\
\hline & & p-value & 0.000 & 0.007 & 0.027 \\
\hline & South & FP test & 8.51 & 15.54 & 11.56 \\
\hline & & p-value & 0.000 & 0.000 & 0.000 \\
\hline & & & 1980-1989 & 1990-1999 & $2000-2011$ \\
\hline & & & $\mu$-EINino $/ \mu$-LaNina/ $\mu$-Neutro & $\mu$-EINino $/ \mu$-LaNina/ $\mu$-Neutro & $\mu$-EINino/ $\mu$-LaNina/ $\mu$-Neutro \\
\hline & & & & Joint analysis & \\
\hline & & FP test & 49.54 & 78.72 & 23.30 \\
\hline b) $T \max$ & & $p$-value & 0.000 & 0.000 & 0.000 \\
\hline & & & & Mega-region analysis & \\
\hline & Center & FP test & 14.38 & 29.05 & 5.80 \\
\hline & & p-value & 0.000 & 0.000 & 0.000 \\
\hline & East & FP test & 6.99 & 6.84 & 9.05 \\
\hline
\end{tabular}




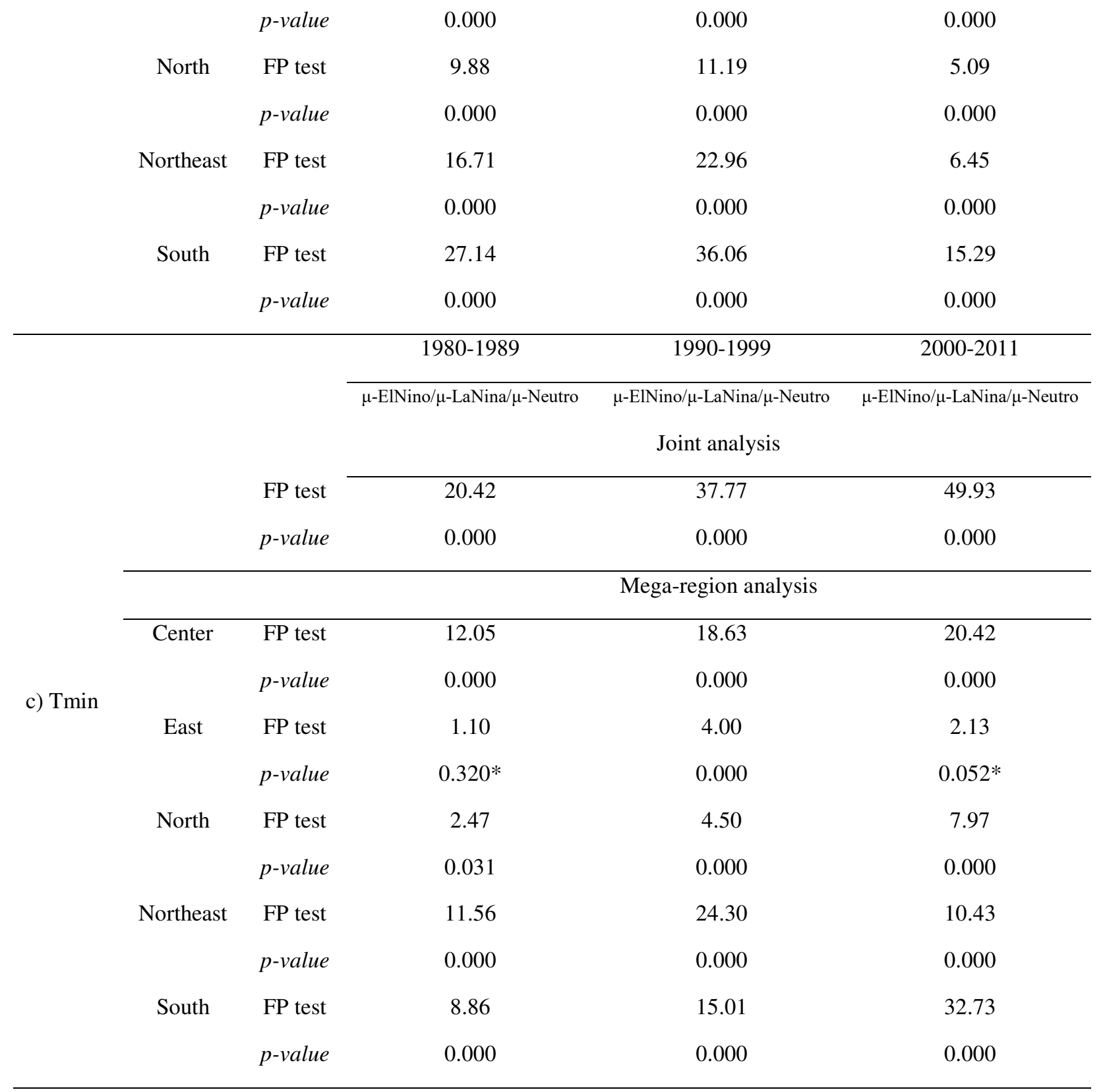


Table 3. Hypothesis test based on the SCB for mean functional estimated for a) accumulated rainfall (Prec), b) maximum temperature (Tmax), and c) minimum temperature (Tmin) across the three investigated periods for ENSO conditions (El Niño, La Niña, and Neutral) considering only the joint analysis (entire Goiás Sate).

\begin{tabular}{|c|c|c|c|c|c|}
\hline & \multirow[b]{2}{*}{ ENSO } & & \multicolumn{3}{|c|}{ Period } \\
\hline & & & 1980-1989 & 1990-1999 & $2000-2011$ \\
\hline & & & & Joint analy & \\
\hline \multirow{6}{*}{ a) Prec } & $\begin{array}{l}\mu \text {-ElNino/ } \\
\mu \text {-LaNina }\end{array}$ & $\begin{array}{c}\text { Statistic } \\
\text { Test }\end{array}$ & 13.40 & 10.03 & 7.86 \\
\hline & & p-value & $1 \mathrm{e}^{-16}$ & $1 \mathrm{e}^{-16}$ & $1 \mathrm{e}^{-16}$ \\
\hline & $\begin{array}{l}\mu \text {-EINino/ } \\
\mu \text {-Neutral }\end{array}$ & $\begin{array}{c}\text { Statistic } \\
\text { Test }\end{array}$ & 9.90 & 10.38 & 11.39 \\
\hline & & p-value & $1 e^{-16}$ & $1 \mathrm{e}^{-16}$ & $1 \mathrm{e}^{-16}$ \\
\hline & $\begin{array}{c}\mu \text {-LaNina/ } \\
\mu \text {-Neutral }\end{array}$ & $\begin{array}{c}\text { Statistic } \\
\text { Test }\end{array}$ & 16.15 & 12.53 & 5.86 \\
\hline & & p-value & $1 \mathrm{e}^{-16}$ & $1 \mathrm{e}^{-16}$ & $1 \mathrm{e}^{-16}$ \\
\hline \multirow{6}{*}{ b) $T \max$} & $\begin{array}{c}\mu \text {-ElNino } / \\
\mu \text {-LaNina }\end{array}$ & $\begin{array}{c}\text { Statistic } \\
\text { Test }\end{array}$ & 16.23 & 20.71 & 14.26 \\
\hline & & p-value & $1 e^{-16}$ & $1 e^{-16}$ & $1 \mathrm{e}^{-16}$ \\
\hline & $\begin{array}{l}\mu \text {-EINino/ } \\
\mu \text {-Neutral }\end{array}$ & $\begin{array}{c}\text { Statistic } \\
\text { Test }\end{array}$ & 16.78 & 19.09 & 15.12 \\
\hline & & p-value & $1 e^{-16}$ & $1 \mathrm{e}^{-16}$ & $1 \mathrm{e}^{-16}$ \\
\hline & $\begin{array}{c}\mu \text {-LaNina/ } \\
\mu \text {-Neutral }\end{array}$ & $\begin{array}{c}\text { Statistic } \\
\text { Test }\end{array}$ & 16.54 & 11.05 & 14.00 \\
\hline & & p-value & $1 e^{-16}$ & $1 \mathrm{e}^{-16}$ & $1 \mathrm{e}^{-16}$ \\
\hline \multirow{6}{*}{ c) Tmin } & $\begin{array}{l}\mu \text {-EINino/ } \\
\mu \text {-LaNina }\end{array}$ & $\begin{array}{c}\text { Statistic } \\
\text { Test }\end{array}$ & 7.37 & 8.50 & 15.45 \\
\hline & & p-value & $1 \mathrm{e}^{-16}$ & $1 \mathrm{e}^{-16}$ & $1 \mathrm{e}^{-16}$ \\
\hline & $\begin{array}{l}\mu \text {-ElNino/ } \\
\mu \text {-Neutral }\end{array}$ & $\begin{array}{c}\text { Statistic } \\
\text { Test }\end{array}$ & 11.49 & 15.04 & 7.24 \\
\hline & 1 & $p$-value & $1 e^{-16}$ & $1 \mathrm{e}^{-16}$ & $1 \mathrm{e}^{-16}$ \\
\hline & $\begin{array}{c}\mu \text {-LaNina/ } \\
\mu \text {-Neutral }\end{array}$ & $\begin{array}{c}\text { Statistic } \\
\text { Test }\end{array}$ & 10.72 & 12.15 & 10.43 \\
\hline & & p-value & $1 \mathrm{e}^{-16}$ & $1 \mathrm{e}^{-16}$ & $1 \mathrm{e}^{-16}$ \\
\hline
\end{tabular}


Table 4. Mean number of days needed for a) accumulating the minimum amount of rainfall to allow the start of crop sowing season in the region (Heinemann et al. 2021) and b) accumulated $500 \mathrm{~mm}$

\begin{tabular}{|c|c|c|c|}
\hline \multirow[b]{2}{*}{ ENSO } & \multicolumn{3}{|c|}{ Period } \\
\hline & $1980-1989$ & $1990-1999$ & $2000-2011$ \\
\hline & \multicolumn{3}{|c|}{$\begin{array}{l}\text { a) mean number of days to allow the start of } \\
\text { crop sowing season (accumulated } 43 \mathrm{~mm} \text { ) }\end{array}$} \\
\hline El Niño & 11 & 19 & 13 \\
\hline La Niña & 19 & 16 & 16 \\
\hline Neutral & 12 & 13 & 15 \\
\hline Mean & 14.0 & 16.0 & 14.7 \\
\hline \multirow[t]{2}{*}{ SD } & 4.4 & 3.0 & 1.5 \\
\hline & \multicolumn{3}{|c|}{ b) Mean number of days to accumulate $500 \mathrm{~mm}$} \\
\hline El Niño & 85 & 89 & 80 \\
\hline La Niña & 87 & 85 & 80 \\
\hline Neutral & 75 & 84 & 81 \\
\hline Mean & 82.3 & 86.0 & 80.3 \\
\hline SD & 6.4 & 2.6 & 0.6 \\
\hline
\end{tabular}

SD - standard deviation 


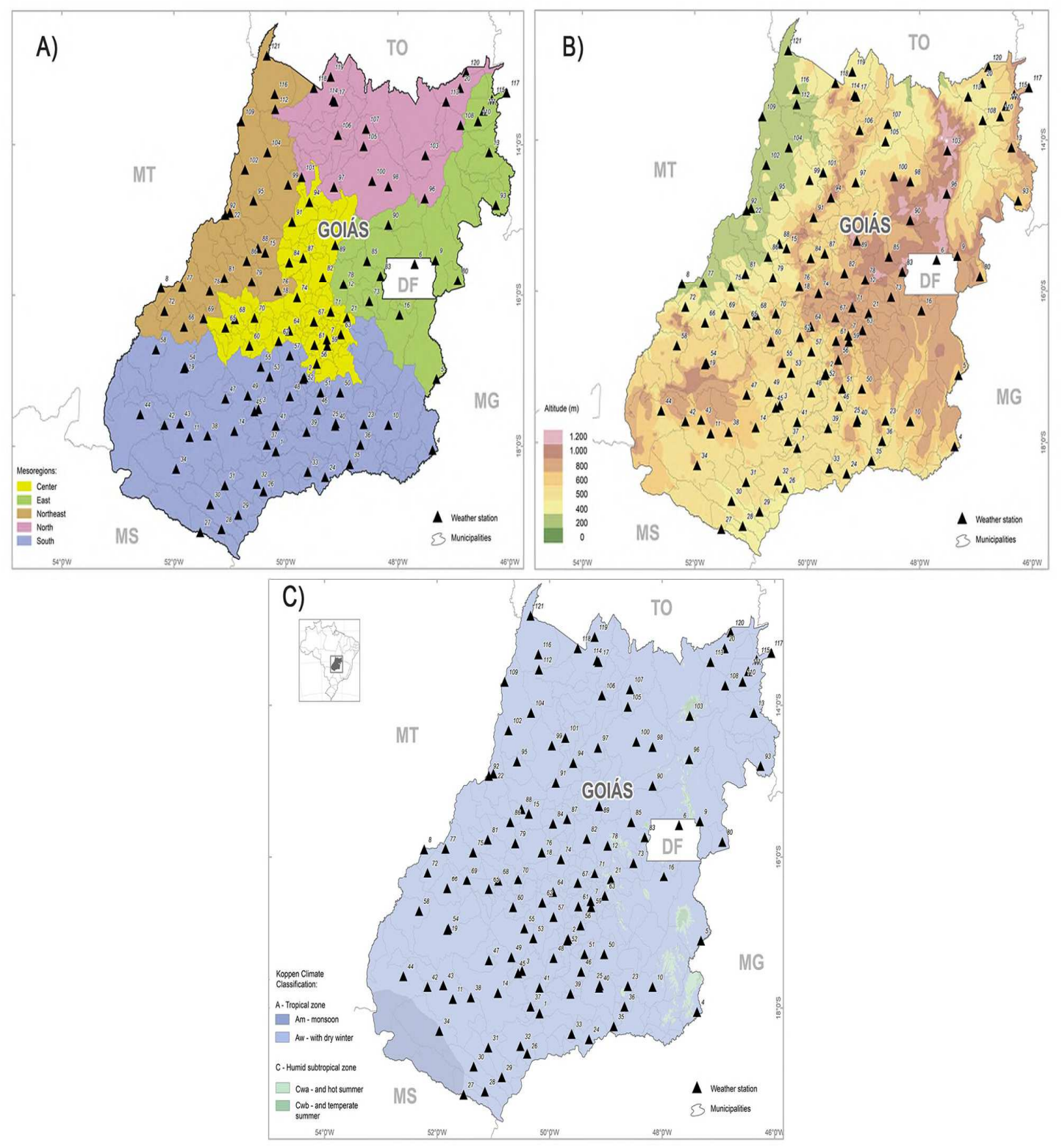

Figure 1. Geographic distribution of the weather stations. A) mega-regions, B) altitude above sea level (m), and C) climate in the study region. 


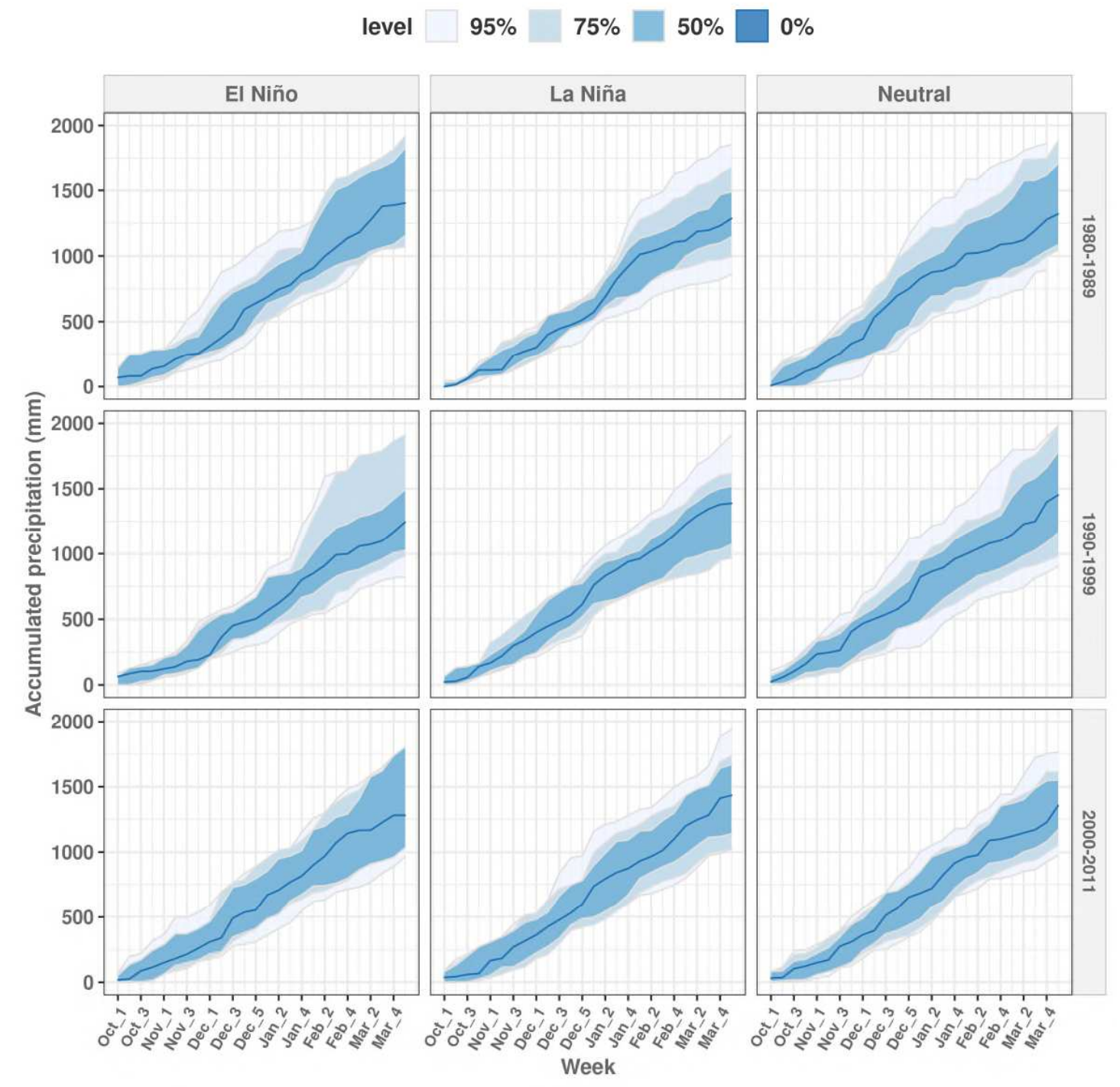

Figure 2. Functional statistics for accumulated rainfall data set, in mm, across ENSO conditions (top panel) and time periods (right panel) for 121 weather stations (Goiás joint analysis). $0 \%$ represents the median curve. $50 \%$ is the central region. $75 \%$ represents the non-outlying extreme curves. $90 \%$ represents outlier candidates detected by 1.5 times the $50 \%$ central region rule. 


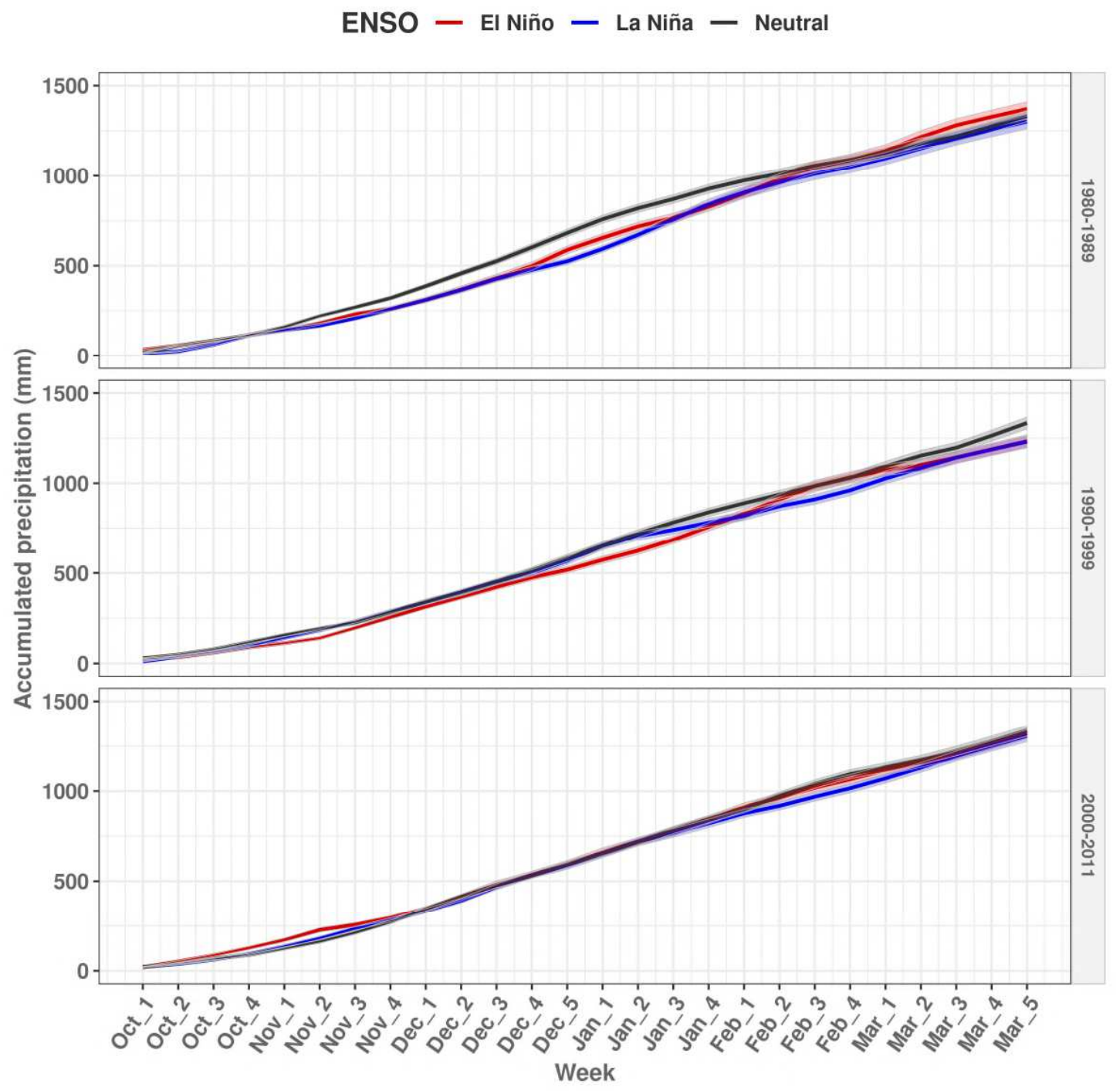

Figure 3. Mean functional estimation (MFE) and its simultaneous confidence bands (SCB, shading) for accumulated rainfall (mm) for ENSO conditions (La Niña, El Niño, and Neutral) across three periods (right panel) for 121 weather stations. 


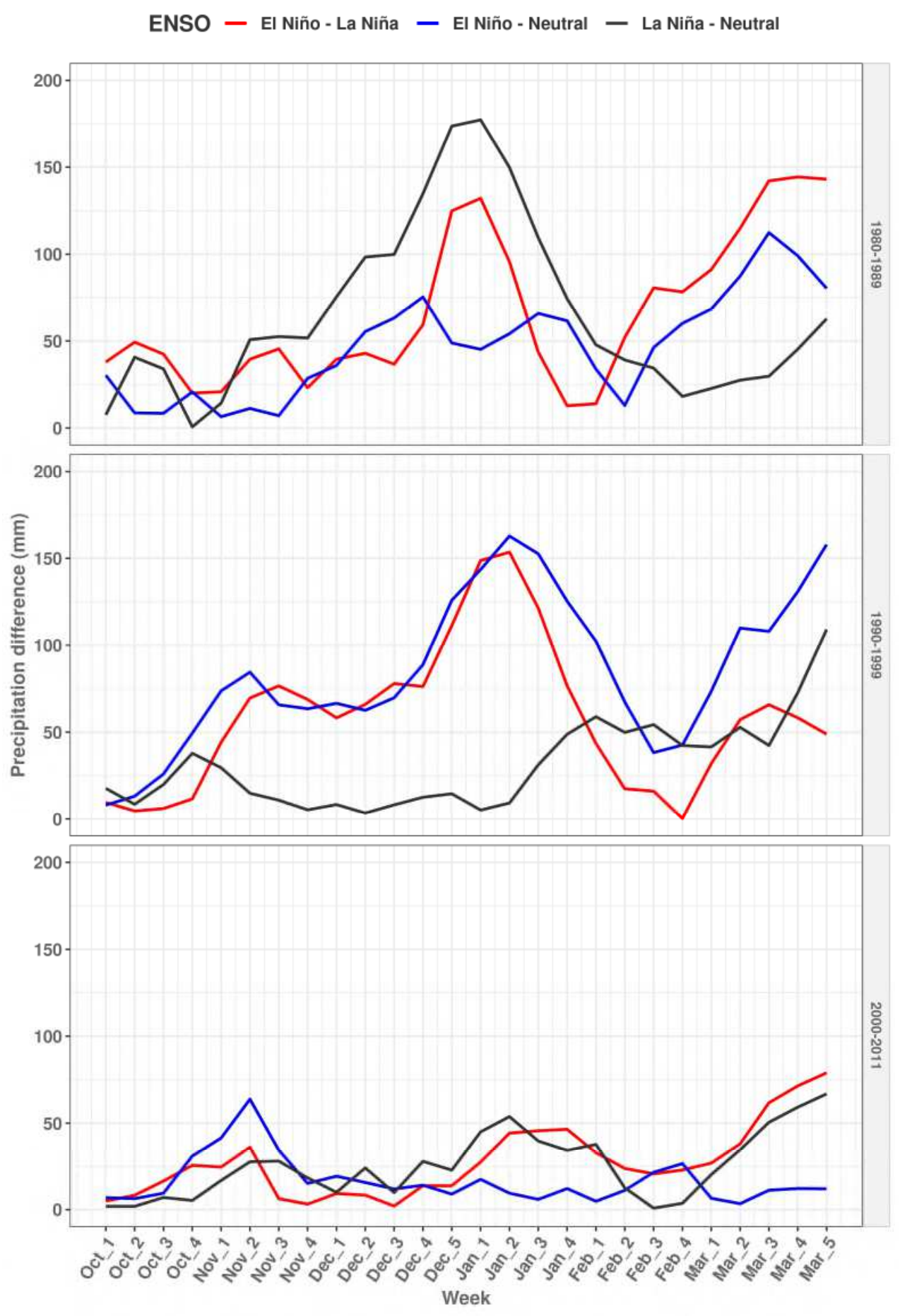

Figure 4. Difference among the mean functional estimated (MFE) for accumulated rainfall (mm) for ENSO conditions (El Niño - La Niña; El Niño - Neutral, and La Niña - Neutral) in absolute values (mm) in the three investigated periods (right panel). 


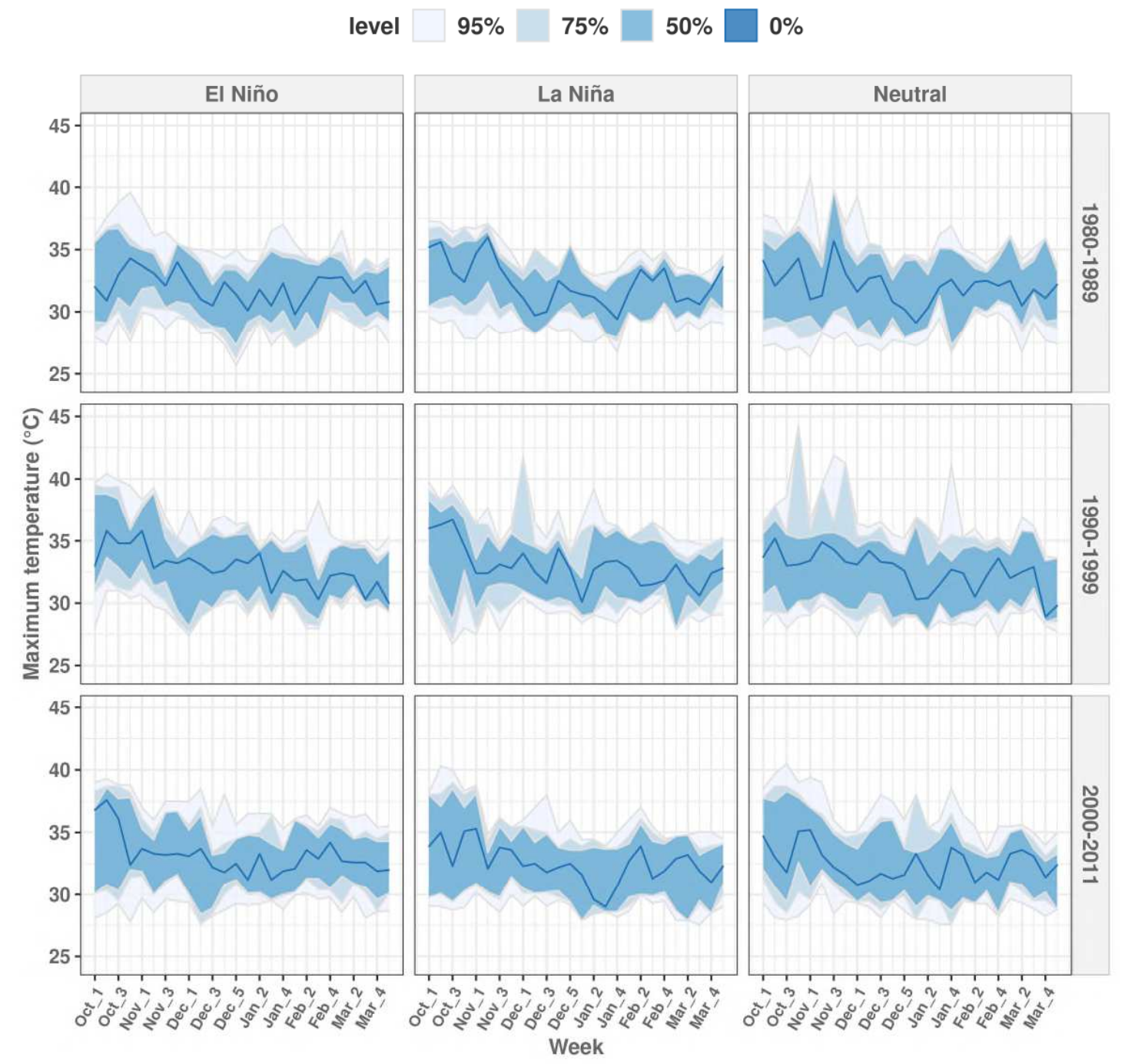

Figure 5. Functional statistics for maximum temperature data set, in C, in ENSO conditions (top panel) and periods (right panel) for 121 weather stations (Goiás - joint analyses). $0 \%$ represents the median curve, $50 \%$ is the central region, $75 \%$ represents the non-outlying extreme curves, and $90 \%$ represents the outlier candidates detected by 1.5 times the $50 \%$ central region rule. 


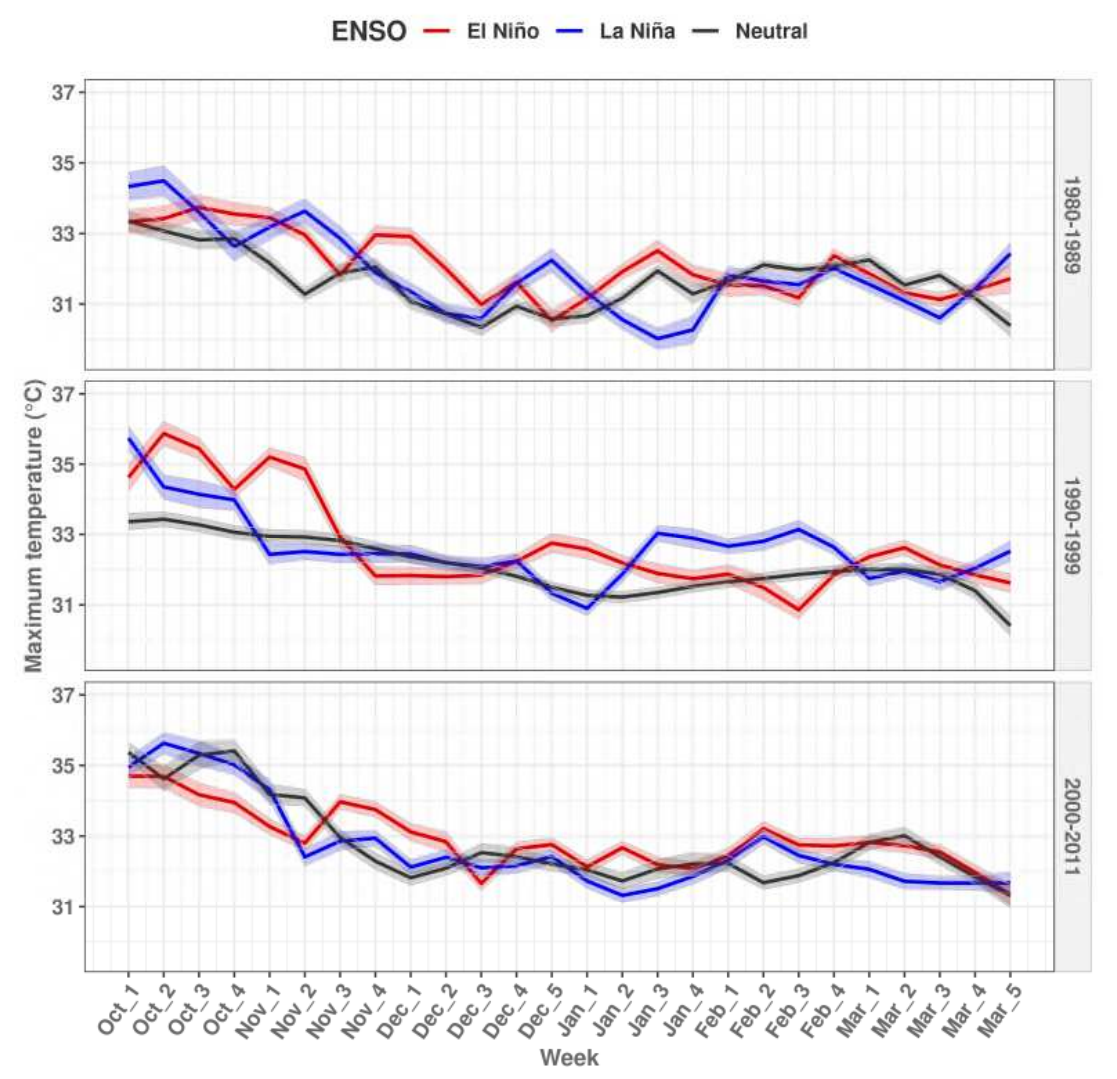

Figure 6. Mean functional estimation (MFE) and its simultaneous confidence bands (SCB, shading) for maximum temperature $\left({ }^{\circ} \mathrm{C}\right)$ in ENSO conditions (La Niña, El Niño, and Neutral) in the three investigated periods (right panel) for 121 weather stations. 


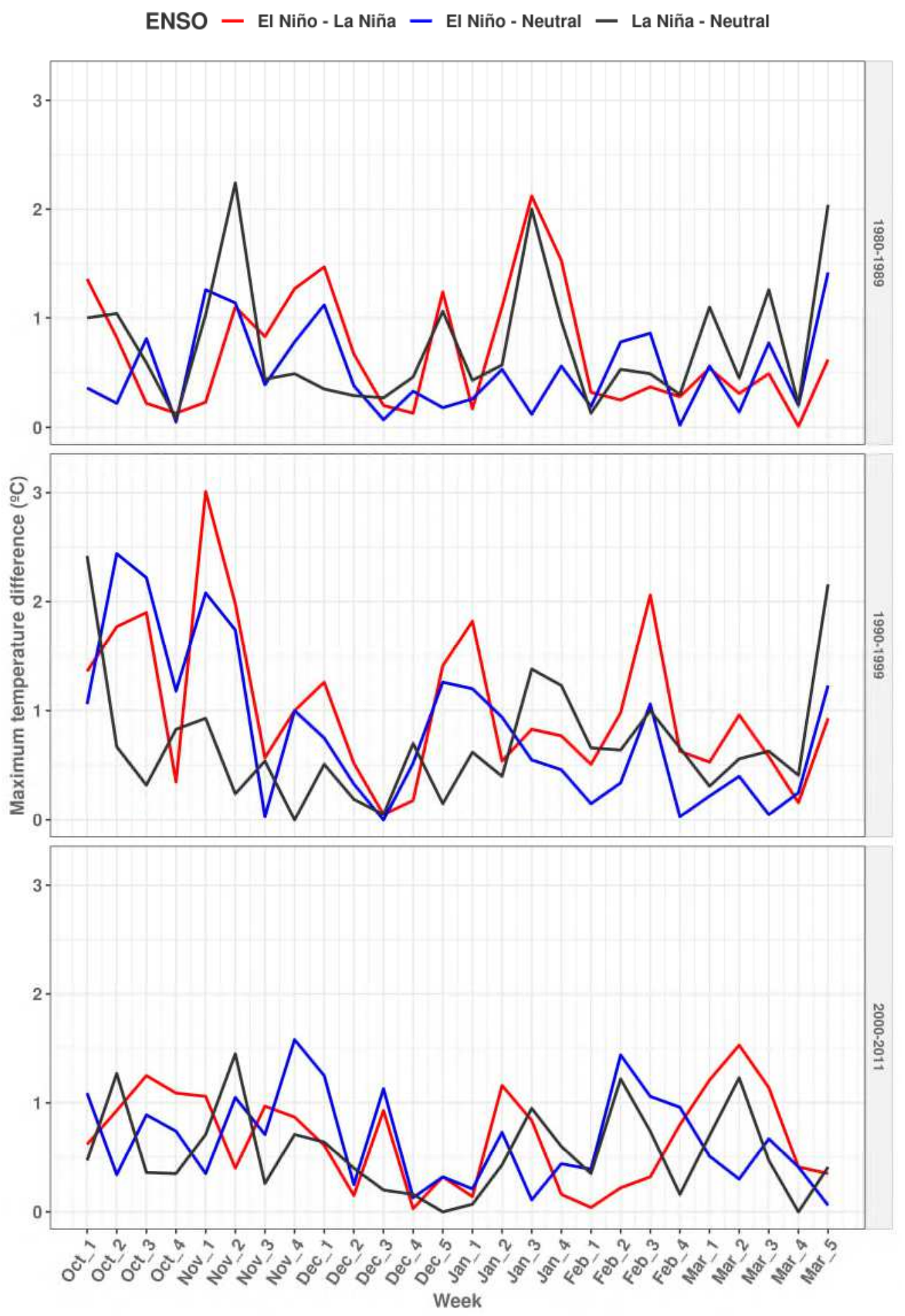

Figure 7. Difference among the mean functional estimate for maximum temperature $\left({ }^{\circ} \mathrm{C}\right)$ for ENSO conditions (El Niño - La Niña; El Niño - Neutral and La Niña -

Neutral) in absolute values across the three investigated periods (right panel). 


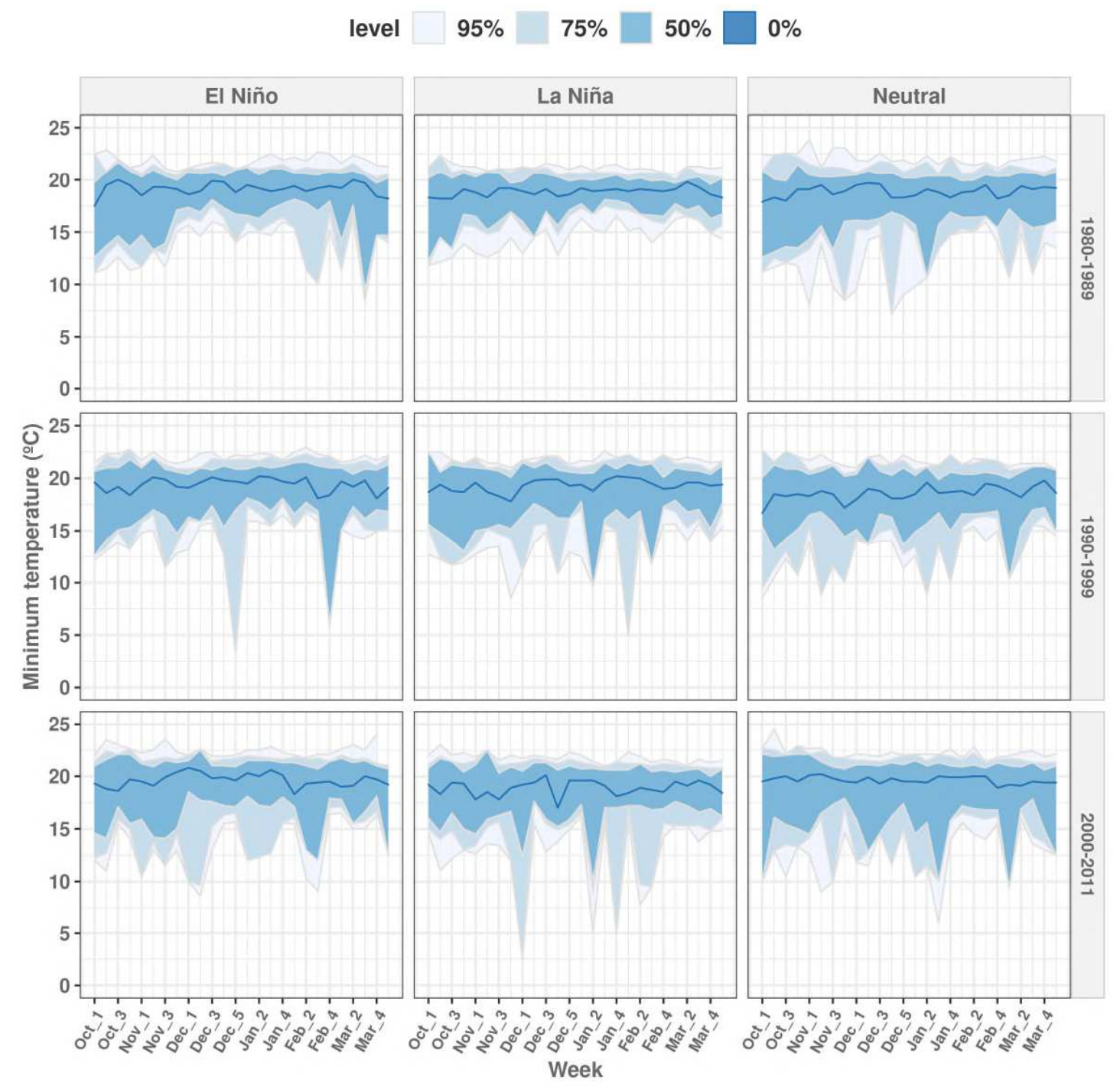

Figure 8. Functional statistics for minimum temperature data set, in C, in ENSO conditions (top panel) and periods (right panel) for 121 weather stations (Goiás - joint analyses). $0 \%$ represents the median curve, $50 \%$ is the central region, $75 \%$ represents the non-outlying extreme curves, and $90 \%$ represents the outlier candidates detected by 1.5 times the $50 \%$ central region rule. 


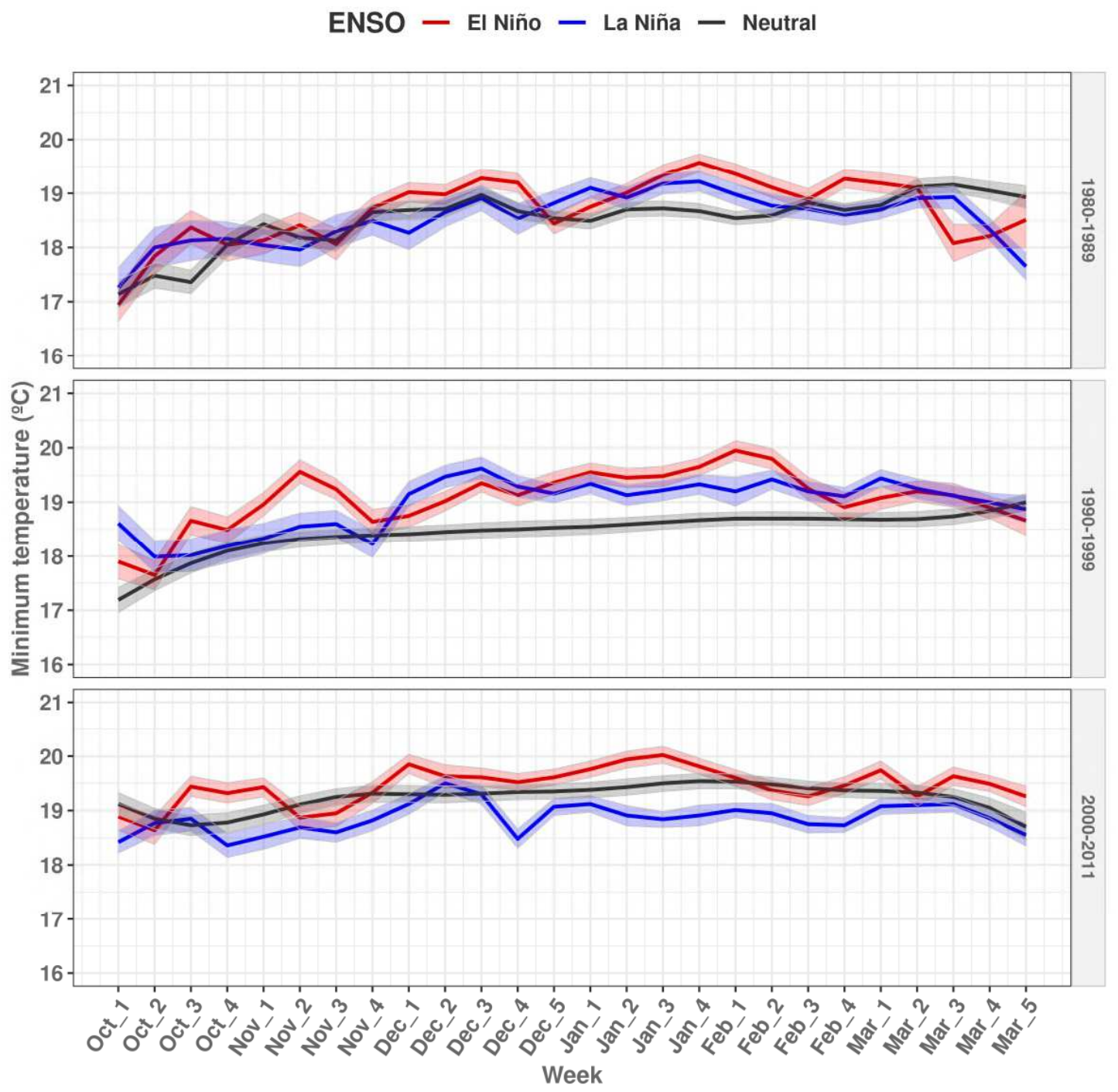

Figure 9. Mean functional estimation (MFE) and its simultaneous confidence bands (SCB, shading) for minimum temperature $\left({ }^{\circ} \mathrm{C}\right)$ for ENSO conditions (La Niña, El Niño, and Neutral) in the three investigated periods (right panel) for 121 weather stations. 


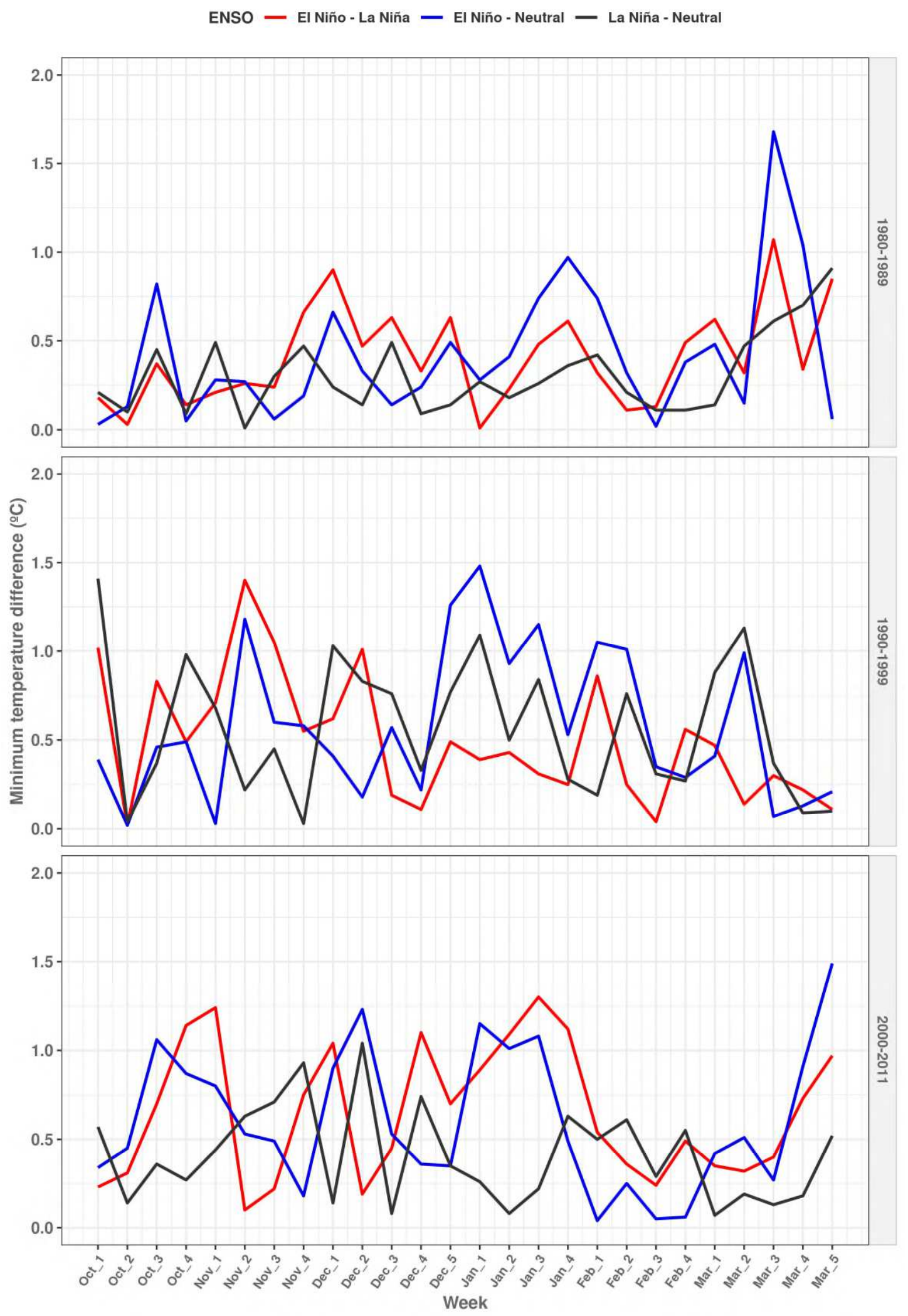

Figure 10. Difference among the mean functional estimate (MFE) for minimum temperature $\left({ }^{\circ} \mathrm{C}\right)$ for ENSO conditions (El Niño - La Niña; El Niño - Neutral and La Niña - Neutral) in absolute values in the three investigated periods (right panel). 


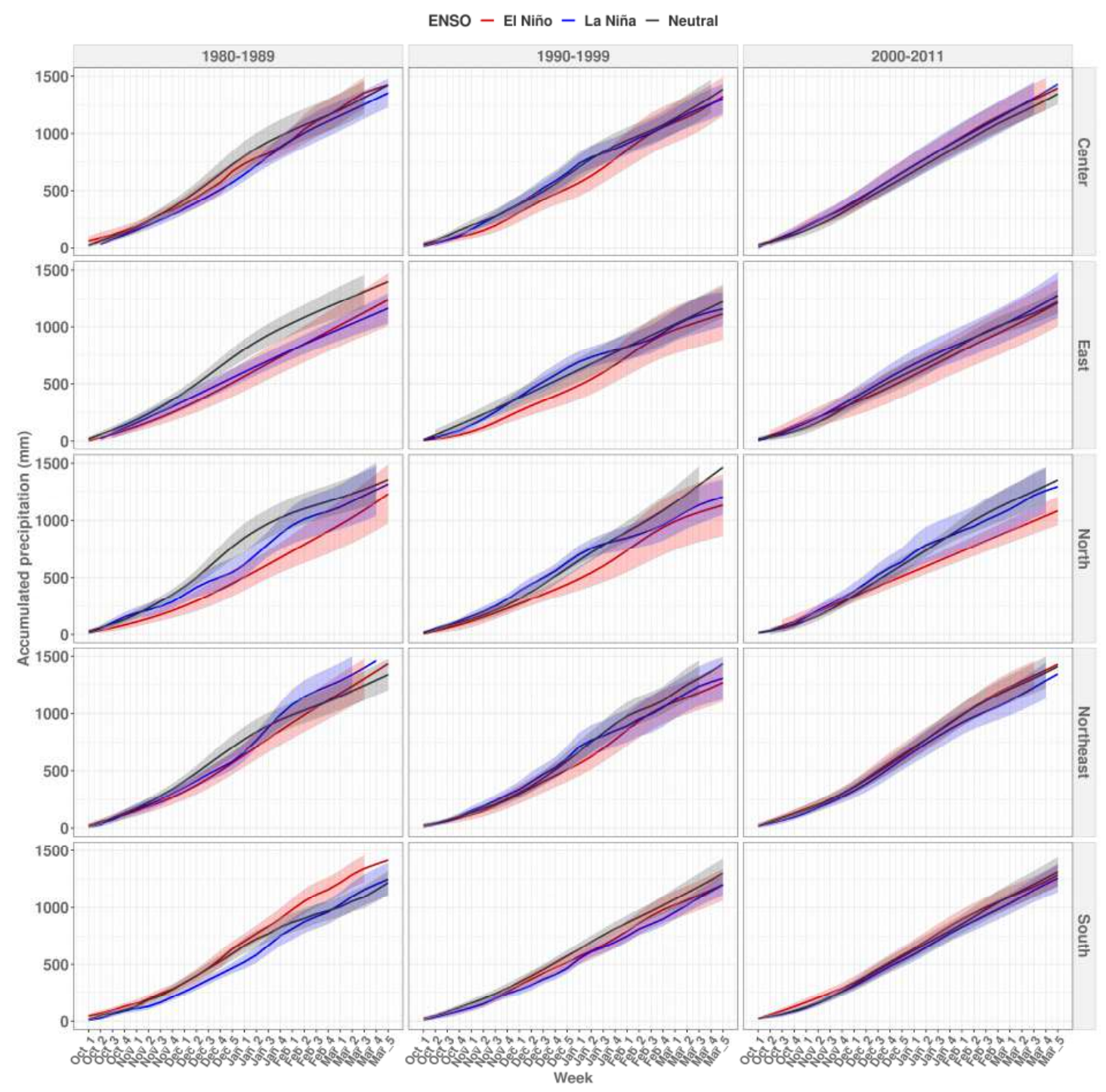

Figure 11. Mean functional estimation (MFE) and its simultaneous confidence bands (SCB -shading) for accumulated rainfall (mm) for ENSO conditions (La Niña, El

Niño, and Neutral) in mega-regions (right panel) and three investigated periods (top panel). 


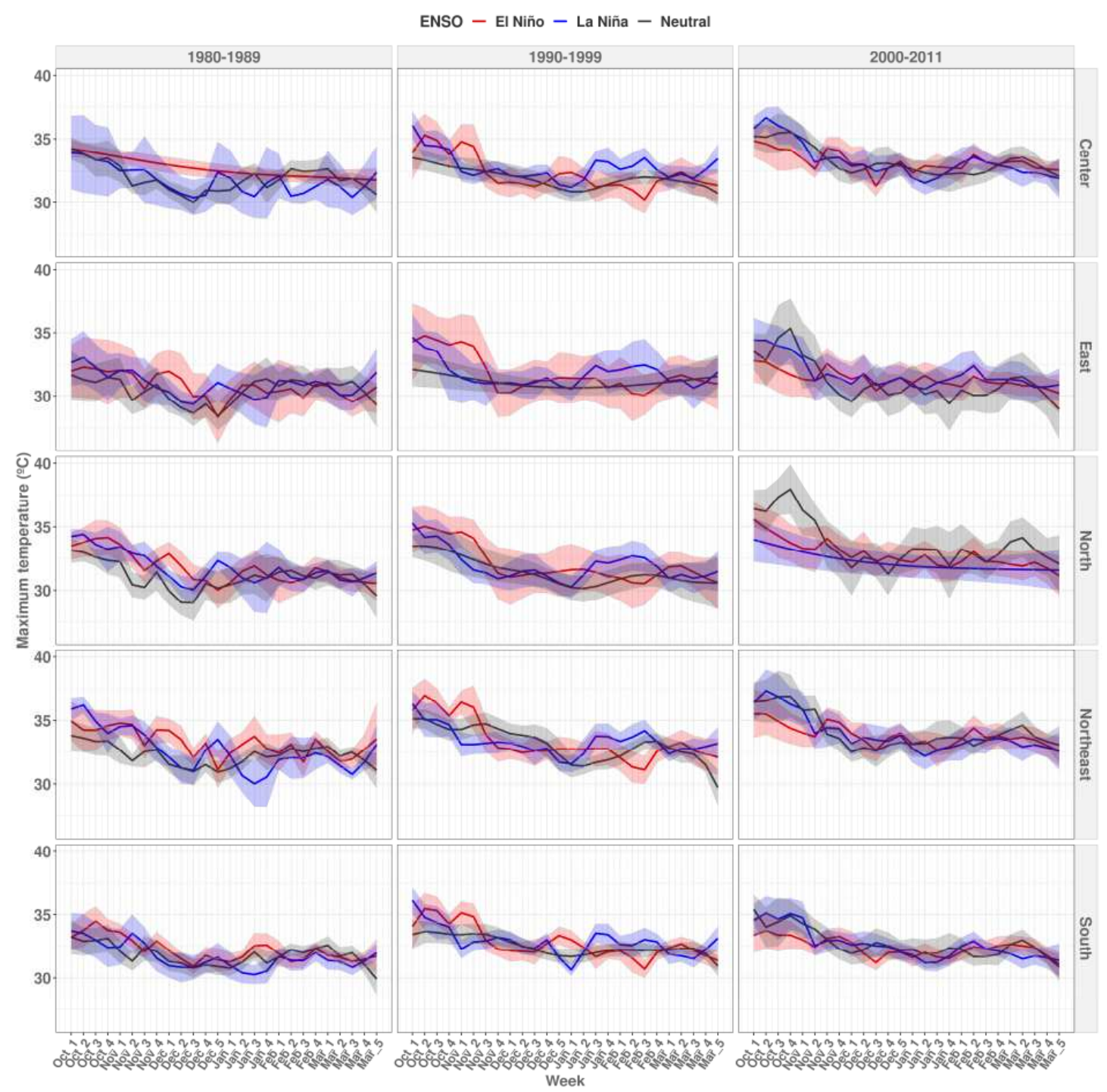

Figure 12. Mean functional estimation (MFE) and its simultaneous confidence bands (SCB, shading) for maximum temperature $\left({ }^{\circ} \mathrm{C}\right)$ for ENSO conditions (La Niña, El Niño, and Neutral) in mega regions (right panel) and three investigated periods (top panel). 


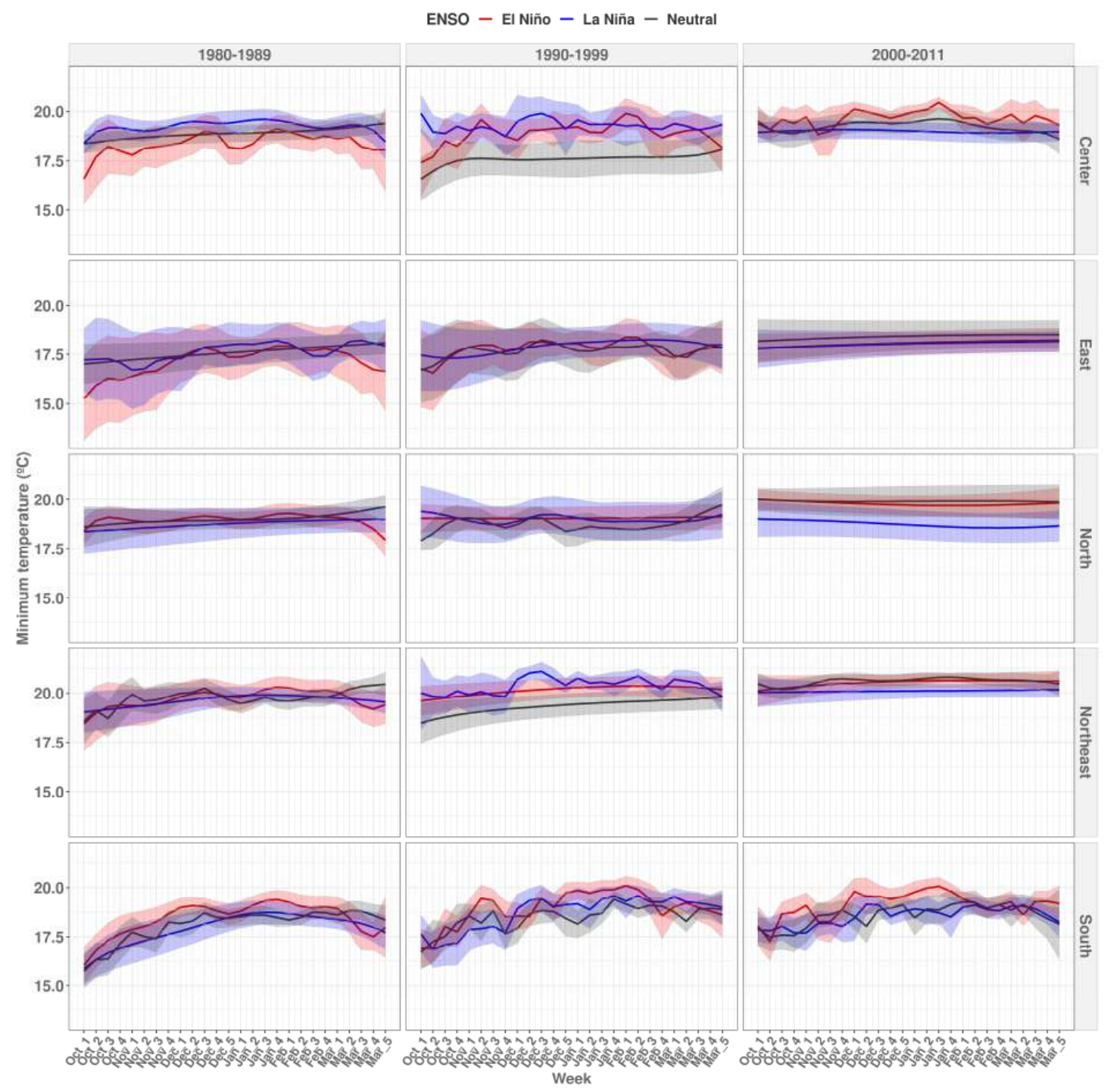

Figure 13. Mean functional estimation (MFE) and its (simultaneous confidence bands (SCB, shading) for minimum temperature $\left({ }^{\circ} \mathrm{C}\right.$ ) for ENSO conditions (La Niña, El Niño, and Neutral) in mega regions (right panel) and three investigated periods (top panel). 


\section{Supplementary Files}

This is a list of supplementary files associated with this preprint. Click to download.

- SIPatternsv5.docx 